\title{
La Revolución Filipina y los recoletos de san Agustín
}

Advertencia preliminar

Cuando nos decidimos a hacer el estudio sobre la Persecución religiosa y la Orden de San Agustín en la independencia de Filipinas ${ }^{1}$ como tesina de licenciatura en la Universidad de Valladolid, teníamos el propósito de su continuación, ahora como tesis doctoral, abarcando la labor de los hermanos recoletos y la de las distintas corporaciones que sufrieron idéntica persecución religiosa en el Archipiélago.

Habiendo realizado nuestra tesis doctoral sobre La Orden de San Agustín en la India, siempre hemos creído un deber de justicia y una atención de hermanos el hacer un estudio sobre la Orden, o mejor, sobre la provincia agustiniana recoleta de san Nicolás de Tolentino en Filipinas y la persecución que sufrieron, al igual que los agustinos de la provincia del Santísimo Nombre de Jesús, muchos de sus religiosos.

De este modo, cumplimos con los deseos que nos han manifestado por carta y de palabra varios agustinos recoletos los cuales estaban echando en falta el capítulo tan glorioso de la Recolección en Filipinas.

Queremos dar las gracias a la comunidad de Marcilla por la acogida fraternal que nos dispensó en los días en que, aprovechando las vacaciones veraniegas; estuvimos trabajando en su Archivo de Provincia, recogiendo los datos que son la base fundamental de este artículo.

1. APARICIO, T., La persecución religiosa y la Orden de San Agustín en la independencia de Filipinas, Estudio Agustiniano, Valladolid, 1973. 
I. Origenes de una provincia recoleta misionera.

La historia de los agustinos recoletos en Filipinas es una de las más brillantes, más puras y el florón más hermoso de la Corporación. "No se puede negar -escribe en una carta, dirigida al Vi.cario General, el P. José de la Concepción - que la provincia de Filipinas es la niña de los ojos, la gloria, honor y esplendor de la Congregación, como consta de nuestras Crónicas. Y no sólo sino que es la provincia de más estimación, honra y gloria de toda la Descalcez Agustiniana por su aplicación a la propaganda de la fe, por sus gloriosos progresos en la conversión de los infieles, por los imponderables trabajos que experimenta en la administración de los que tiene ya convertidos, y por tantas circunstancias, que quitada de nuestras crónicas la Provincia de Filipinas, se quita el mayor esplendor y gloria de la Congregación" 2

Nota característica a destacar es la labor patriótica que llevaron a cabo estos religiosos, junto a la tarea principal de las misiones y del trabajo apośólico. Precisamente, por eso, destinados a misionar en las islas más extremas del Archipiélago y más próximas al enemigo, ellos fueron los que contuvieron más de una vez a ese enemigo ya venciéndole en lucha abierta contra él ya construyendo a fuerza de trabajos y privaciones fortalezas que al mismo tiempo que servian de escudo contra el adversario, eran la salvaguardia de los pueblos que de otra manera hubieran sucumbido ante el arrojo y la traición de aquel pueblo vecino que parecía haber jurado guerra de exterminio al nombre cristiano.

Cada Cura - sigue diciendo el historiador de la Recolección en Filipinas - era un jefe religioso y militar. La historia de la Recolección cuenta por centenares los hijos que vertieron su sangre en aras de la patria filipina y esa misma Recolección se despojó en más de una ocasión de sus alhajas, hasta de sus escasos recursos, para salvar al pais contribuyendo con ellos al sostenimiento de esas fortalezas ${ }^{3}$. Si, como se ha dicho, las colectividades o sociedades son lo que las hacen sus individuos, la apostólica provincia de San Nicolás de Tolentino, cuna de heróicos misioneros

2. Jose DE LA Concepcion, Carta al P. Vicario General, Archivo Provincial, t. I. de cartas. LICINIo RuIz, Sinopsis histórica de la Provincia de san Nicolás de Tolentino de las Islas Filipinas, v. II, Manila 1925, 534.

3. RUIz, L., o. c., 536. 
y paladines de la verdad, vergel ameno de flores de virtud y ciencia, bien merece por ello los dictados de santa y de sabia.

Pero hagamos un poquito de historia. Los agustinos recoletos llegaron a las islas Filipinas comenzado ya el siglo XVII, exactamente el año 1606. Fue el monarca español Felipe III el que, deseando recompensar de algún modo las bellísimas cualidades que adornaban al P. Juan de San Jerónimo, le presentó para regir la ig:esia de Chiapa, en América. Pero este religioso, humilde de verdad, que huía de todo lo que sonara a cargos y dignidades, aprovechó aquella ocasión favorable del monarca para pedirle le concediera la gracia de poder conducir una barcada, la primera de todas y como entonces se decía de religiosos recoletos de Filipinas. El rey accedió gustoso a aquella súplica dándole real licencia y beneplácito.

Presentada que fue esta licencia regia al Definitorio, y viendo que era "muy del agrado y servicio de Dios nuestro Señor", determinó que el mencionado $P$. Juan se pusiera al frente de la primera expedición compuesta por doce religiosos ", la cual llegó felizmente a la isla de Cebú el 10 de mayo del citado 1606, donde fueron magníficamente recibidos y agasajados por los hermanos agustinos de la provincia del Santísimo Nombre de Jesús, que llevaban allí misionando desde el año de 1565 en que llegaron por primera vez en la expedición comandada por don Miguel López de Legazpi y en la que iba el célebre Andrés de Urdaneta ${ }^{5}$.

A poco de su llegada al Archipiélago, considerada por Fray Pedro de Agurto, entonces obispo de Cebú, como providencial ${ }^{6}$,

4. El P. Marcelino Simonena, en un artículo publicado en el Boletín de la Provincia, febrero de 1910, titulado: Origen de la Provincia de San Nicolás de Tolentino, nos dice que, autorizados ya por la Orden y con cédulas reales para embarcarse y fundar conventos, con facultades del Sr. Nuncio en lo tocante a lo espiritual, el P. Juan fue disponiendo sus obreros, que, como dicen las Crónicas, fueron de lo más granado. $Y$ a continuación nos da los nombres de los doce primeros religiosos agustinos recoletos misioneros en Filipinas: Andrés de San Nicolás, Miguel de Santa Maria, Jerónimo de Cristo, Diego de la Anunciación, Pedro de San Fulgencio, Rodrigo de San Miguel, Francisco Bautista, Francisco de la Madre de Dios, Andrés del Espiritu Santo, y el resto Hermanos de Obediencia, muy útiles, venerados y queridos de todos.

5. Los agustinos de la Provincia del Santísimo Nombre de Jesús de Filipinas llevaban misionando en el Archipiélago desde el año 1565, fecha en que Urdaneta y compañeros de expedición arribaron a las playas de Cebú.

6. En una carta que Fray Pedro de Agurto escribe al rey le dice: "Una de las principales compañías que han venido a estas tierras a la promulga- 
tuvieron que someterse a la obediencia de los hermanos de hábito; lo que naturalmente -escribe el historiador de la Descalcez- tuvo que serles algún tanto penoso y amargo ?. Para fortuna de estos desconsolados recoletos, era provincial de la mencionada provincia agustiniana el P. Pedro Solier; lo cual fue "de múcho alivio", pues había corregido muchas cosas y puesto una observancia regular cual cabía esperar de persona en quien concurrian tantas y tan aventajadas partes de letras, virtud y prudencia ${ }^{8}$.

Restablecida la Recolección en 1610 por el mismo pontífice que la había suprimido, Paulo $V$, las cosas volvieron a su normalidad anterior, restableciéndose de nuevo la autoridad dentro de la Reforma agustiniana, y quedando los recoletos de Filipinas liberados de los hermanos de hábito calzados.

Las anormalidades debieron seguir hasta el año de 1624 en que los recoletos de Filipinas pudieron celebrar el primer capítulo provincial, del cual salió elegido superior mayor el $P$. Onofre de la Madre de Dios ${ }^{9}$.

A partir de este momento, los agustinos recoletos en Filipinas trataron de emular el trabajo de las demás corporaciones religiosas que de tiempo atrás residían en el Archipiélago.

El primer convento que fundaron fue el de Bagumbayan, junto a la playa de Manila y en unos terrenos destinados en principio para la casa o palacio de recreación del gobernador don Pedro de Acuña ${ }^{10}$. El día diez de septiembre ${ }^{11}$ se inauguraron la iglesia $y$

ción del Evangelio, es la sagrada religión de los Recoletos de mi orden de S. Agustín, cuya doctrina fuera siempre bien recibida porque se predica con vida ejemplar, y agora lo fue mucho más, pues vino a tiempo que pareció particular providencia del cielo la llegada de estos padres recoletos, que templaron con su trato suave y santo algunas discordias que en su orden de la observancia habian levantado y obligándome a venir de mi obispado a sosegar mis hermanos". (Cit. por Licinio Ruiz. o.c., I,7).

7. Ibid., I, 7 .

8. E. P. Eustasio Esteban cree que la supresión de los agustinos recoletos obedeció a los abusos que los mismos religiosos denunciaron al Sr. Nuncio, Decio, el cual nombró un Visitador al efecto. Este fue el P. M. Francisco Pereira, lusitano, y en tiempo del $P$. Juan de Vera, prior que había sido del convento de San Felipe el Real, nombrado Comisario de los Descalzos por el P. General el año 1597. (Conf. Analecta Agustiniana, 1924, p. 84, y 331).

9. Como definidores fueron nombrados los religiosos Andrés del Espíritu Santo, Diego de San Bernardo, José de San Agustín y Juan de Santo Tomás.

10. A la muerte de Acuña, su sucesor, don Pedro de Ortega, a instancias y ruegos del Fiscal de la Audiencia, don Rodrigo Díaz Guiral, Ia 
convento con una solemnisima fiesta, a la que concurrieron todas las corporaciones de religiosos existentes en Filipinas, el Cabildo Catedral, la Real Audiencia, y todo lo más principal y granado de la ciudad de Manila, predicando el P. Solier y celebrando la misa de pontifical el citado obispo de Cebú, Fray Pedro de Agurto.

Dos años más tarde de este acontecímiento, los agustinos recoletos verian con satisfacción cómo las misiones que poco tiempo atrás, en 1607, se habían fundado en Zambales comenzaban a dar copiosos frutos; verían también cómo los hermanos extendían sus conquistas espirituales por Mindanao y Paragua; cómo se multiplicaban luego los conventos en todas partes; cómo, en fin, aquel pequeño grano de mostaza que había comenzado con un grupo de religiosos pobres y sin recursos de ninguna clase fructificaba y se dilataba por muchas partes del archipiélago de Magallanes, de Legazpi y de Urdaneta ${ }^{12}$.

La provincia de Zambales es la primera que les cupo en suerte evangelizar a los agustinos recoletos en Filipinas ${ }^{13}$. Una misión dura y difícil, pues, como señala el cronista, los habitantes de Zambales distinguíanse por su fiereza, y su religión estaba llena de supersticiones ridículas. Tenían sus sitios o lugares reservados en el monte, y en él sus particulares penates o diosecillos a quienes ofrecían sus sacrificios, ejecutándolos unos viejos ilusos y ceremoniosos, a quienes acompañaban unas viejas que decían "catalonas", tenían una gran autoridad sobre la gente ignorante y su religión consistía en una serie de observancias vanas; en política, estaban sujetos y esclavos del más fuerte ${ }^{14}$.

Pronto aquella misión tuvo su protomártir en la persona del fervoroso P. Miguel de Santa María, el cual, predicando en una

vendió a los agustinos recoletos por la cantidad de 3.000 pesos, que los religiosos obtuvieron de limosna.

11. Es significativa la fecha, por cuanto en este día la Iglesia y la Orden de San Agustín celebran la festividad de San Nicolás de Tolentino y la nueva provincia misionera agustiniana de Filipinas habría de llevar precisamente este nombre y patrón.

12. El primer convento recoleto -el de Bagumbayan- fue demolido por el gobernador general de Filipinas, don Sebastián Hurtado de Corcuera, por temor a los temidos piratas holandeses que, por su cercanía a la playa, podían tomarlo fácilmente y hacerse fuertes en él.

13. Los primeros misioneros de esta región fueron los religiosos Miiguel de Santa María, Pedro de San José y Francisco de Santa Mónica.

14. RuIz, L., Sinopsis..., I, 20.- JUAN DE LA Concepcion, Historia General de Filipinas, IV, 255. 
ocasión a aquellas gentes sobre las excelencias de la religión cristiana, recibió por todo premio una lluvia de piedras que le dejó casi exánime, muriendo poco después a causa de las contusiones y heridas en la ciudad de Manila. Tal vez esta sangre generosa sirviera de alimento y vida para la semilla que se habia arrojado en aquella tierra y para la que seguirían echando los nuevos operarios que habrian de venir en pos ${ }^{15}$.

En cinco años que llevaban misionando por aquellos lugares de Zambales los agustinos recoletos fundaron doce pueblos, con sus pequeñas iglesias y sus respectivos conventos. Estos pueblos se extendían a lo largo de la costa de la mencionada región, pues el escaso número de operarios no permitía penetrar en los montes, en los que habitaba una raza de gente más degradada, si bien seguramente más dócil para recibir la palabra de Dios, como lo va a demostrar después. Esta tarea de reducir y civilizar a los infieles de los montes sería obra de tiempo y de la abundancia de misioneros.

La provincia recoleta de Filipinas se extenderá más tarde por distintos puntos de las islas, fundando en todos ellos conventos, iglesias y escuelas alli donde ya existian cristianos, o misiones vivas en regiones más apartadas adonde todavia no habian llegado otras corporaciones.

Son famosos los conventos de Manila intramuros, con una magnifica iglesia, de elegante y esbelta torre y grandiosa fachada, estilo colonial que datan de la segunda mitad del siglo XVIII. Convento que, según carta del $P$. Mateo de la Encarnación, dirigida al rey de España en 1750, era y fue siempre el principal de la provincia; única casa de observancia, donde se guarda el rigor de nuestras sagradas leyes en el modo que permite este clima, sin que a su regular observancia le exceda convento alguno de nuestra España. Es uno de los muchos relicarios de perfección, virtud y ejemplo de los muchos que adornan y hermosean a esta noble y leal ciudad de Manila. Seminario de letras, es también casa de refugio,

15. Es famoso el P. Rodrigo de San Miguel, espíritu verdaderamente grande y emprendedor, fundador de los conventos de Mariveles y Bagas; fundador de cinco pueblos en Zambales; excelente misionero que cuenta por millares las almas convertidas a la fe cristiana. (Conf. SaDABA DEL CARMen, Francisco, Catálogo de los Religiosos Agustinos Recoletos de la Provincia de San Nicolás de Tolentino, de Filipinas, Madrid 1906, 38. 
alivio y consuelo de todos los religiosos que por fatigados y viejos no pueden soportar el gravísimo peso del ministerio; y enfermería general de todos los enfermos actuales y habituales de la provincia. Es, últimamente, casa de Noviciado para los que toman aquí nuestra santo hábito; y de ejercicios espirituales en que los religiosos se emplean en la asistencia del Coro en el rigor de la observancia en ayunos, disciplinas y otras penitencias, para salir fortificados contra todo el poder del infierno a la conversión de los infieles y administración de los ya convertidos de nuestro cargo ${ }^{16}$.

El convento de Cavite, dedicado a Santa Mónica, próximo también a Manila; el de San Sebastián; el célebre convento de Cebú en las islas Visayas, en la ciudad del mismo nombre y donde arribaron los primeros misioneros del Archipiélago..., son otras tantas fundaciones recoletas que dieron días de gloria y esplendor a la congregación.

Importantes y memorables fueron, asimismo, las misiones que estos misioneros agustinos fundaron en la isla de Mindanao, doncie muchos de ellos dejaron sus vidas en el mejor de los testimonios que se puede ofrecer por un gran ideal ${ }^{17}$.

Casi simultánea a la conquista espiritual de Mindanao fue la de las islas llamadas Cuyos, Calamianes y Paragua. Siguiendo siempre los pasos de sus hermanos, los agustinos calzados, los recoletos de Filipinas extendieron sus tareas apostólicas fuera del Archipiélago. Como, por ejemplo, las misiones del Japón a principios del XVII, con los esforzados Francisco de Jesús y el portugués Vicente de San Antonio; Melchor de San Agustín y Martín de San Nicolás, martirizados al igual que sus compañeros y venerados hoy en los altares.

Dentro de las mismas islas Filipinas, abrirán nuevas misiones en la provincia de Romblón, levantando iglesias y conventos en muchos de sus pueblos, como los de Looc, Corcuera, Banton, Cajidiocan, Magallanes, Azagra y San Fernando.

Misiones nuevas en la extensa isla de Luzón, en Mindoro, Masbate, Ticao, Burias y Albay; Bohol, Islas Marianas, isla de Siquijar...; campos nuevos y afanes apostólicos que, a medida que cre-

16. RUIZ, $L$., O.c., I., 107-8.

17. El cronista inserta en su libro la lista de los religiosos que padecieron glorioso martírio en esta isla. (Vid. Sinopsis, I., 171-2) 
cía el número de misioneros, se iban acrecentando y realizando en hermosos frutos de conversión por el país "de las Siete Mil Islas".

Lo mismo que los religiosos agustinos de la provincia del Stmo. Nombre de Jesús de Filipinas, la recoleta de San Nicolás de Tolentino se había alimentado y sostenido durante dos centurias con los religiosos recolectados en las distintas provincias y conventos de España. Hasta que se vio precisada a fundar, como hiciera aquella en Valladolid, un convento en la villa de Alfaro (Logroño), que fue, a juicio del historiador, como el inicio de una nueva era para la congregación, pues de allí habrian de salir los elementos que sostuviesen su mermada existencia en su carrera de luchas, y aún más, los elementos que en días no lejanos restableciesen aquellas provincias fenecidas, viniendo a ser ella la madre fecunda de innumerables hijos que llevasen su nombre y su fama por ambos hemisferios ${ }^{18}$. Sólo que, mientras el convento -Casa Madre de la provincia del Santísimo Nombre de Jesús de Filipinas - data de mediados del siglo XVIII y fue levantado de nueva planta, este de Alfaro fue adquirido por los recoletos ya bien entrado el XIX, exactamente el año $1824^{19}$.

Efímera debió de ser la vida del convento logroñés; pues el que había comenzado con tan buenos auspicios ${ }^{20}$, moría, por decirlo así, al poco tiempo de su adquisición y solamente tuvo cuatro años de existencia, ignorándose los motivos por qué se determinaron tan pronto a abandonar aquel monasterio, antigua propiedad de los monjes de San Antonio Abad.

Se pensó entonces en buscar otro lugar donde llevar adelante los propósitos de fundación en la Metrópoli. Parece ser que recorrieron varios pueblos; hasta que llegada la noticia al de Monteagudo, de Navarra, los principales del pueblo se reunieron en consejo y por unánime acuerdo y por primera provisión comisionaron a dos de ellos para que, avistándose con el rector del citado con-

18. Ibid., II., 2

19. Leyendo la historia de la fundación del convento de Alfaro, aprovechando un viejo y pobre edificio que en las afueras de la villá existía y que fue propiedad de religiosos de San Antonio Abad, vemos cómo pasó por no pequeñas vicisitudes y contrariedades desde que el 1818 se iniciaron los primeros pasos por el P. Alonso Jubera de la Concepción, hasta el día 29 de junio de 1824 , fecha en que, por fin, fue inaugurado solemnemente y admitidos los seis primeros novicios.

20. El convento contaba al año siguiente de ser adquirido 25 novicios. 
vento de Alfaro, manifestasen a éste su voluntad y le propusieran el traslado de la comunidad al santuario de Nuestra Señora del Camino, bajo las bases que ya habían convenido el municipio y la veintena de hombres buenos allí reunidos con tal ocasión.

La fecha del traslado e inauguración fue la del 22 de marzo de 1829. "La venerable y santa provincia de agustinos recoletos de las Islas Filipinas - diría con tal motivo en la función religiosa Fray Justo del Espíritu Santo, Vicario General- instituto no conocido hasta entonces en Navarra, ha dado en dicho día una función tan solemne como religiosa, no solamente a la villa y habitantes de Monteagudo, sino además a tantos millares de almas cuantas de Navarra y Aragón se juntaron en su distrito" ${ }^{21}$.

El colegio de Monteagudo en atención a los fines para que fue fundado, que eran proporcionar misioneros para Ultramar, fue al igual que los de Valladolid, Ocaña y Pastrana, pertenecientes a los agustinos calzados, dominicos y franciscanos respectivamente, reconocidos por el Gobierno en sus tratados y legislación, sobre todo cuando la célebre y tristemente famosa "desamortización" de Mendizábal.

Son muchos los religiosos que se han formado en este monasterio y los que han muerto en él en olor de santidad; hasta el punto de que fue el alma y la inspiración de toda la juventud que se formó a la sombra de sus claustros desde sus principios hasta las últimas décadas del siglo XIX. Uno de ellos, el P. Juan Gascón cuya grandeza de alma, sencillez de corazón y amor divino animan al cronista a dedicarle hermosas páginas en el capítulo que trata del citado convento navarro ${ }^{22}$. Son dignos también de mención los religiosos que murieron en este monasterio, cabe los pies de la Señora José Martínez, Mariano Pena y Francisco Ayarra, misioneros distinguidos en Negros Occidental, en la región tagala de Filipinas, en el Brasil y el último de ellos dignísimo superior de la provincia en las circunstancias más críticas porque haya podido atravesar desde su fundación. Allí duermen también el sueño de los justos el venerable P. Ezequiel Moreno, obispo de Pasto, en Colombia, y

21. Cit. por Licinio Ruiz, II., 75.

22. El historiador de la provincia recoleta, a sabiendas de que alarga las páginas de su relato, no resiste la tentación de extenderse en la biografia de $\tan$ ejemplar religioso. (Vid., Sinopsis, II., 87 ss.). 
el P. Toribio Minguella, religiosos eminentes ambos y escritores distinguidos ${ }^{23}$.

Despojados a la fuerza de la mayor parte y del mejor patrimonio que los recoletos habian administrado en Filipinas, los pueblos de Mindanao, la Corporación que se sentía pujante, buscaba nuevas tierras que fecundizar con la vigorosa sabia de sus hijos que se veian animados, como siempre, a trabajar en aquella aun inculta viña del Señor. Es cierto que a cambio de las parroquias de Mindanao, cedidas al clero secular, les habian concedido los curatos de Cavite; más no eran suficientes para el crecido número de religiosos que enviaba desde la Península el colegio de Monteagudo. Por lo que los superiores trataron de buscar nuevos territorios donde ocupar a sus misioneros, deseosos de trabajar por la extensión del reino de Dios allí donde fuere menester. El Señor quiso que los encontraran, y extensos y prometedores, en la Isla de $\mathrm{Ne}$ gros, una de las más ricas de Filipinas.

A decir verdad, no era nueva aquella isla en la historia de la Recolección. Los recoletos de San Agustín estuvieron presentes en Negros desde el año 1622 en que ya consta administraban el pueblo de Binalgaban ${ }^{24}$. Pero aquella misión no debió perdurar por mucho tiempo, ya que en 1638 es devuelta al mismo sacerdote secular que tiempo atrás había renunciado a la parroquia del citado Binalgaban. Desde esta fecha, se puede decir, no volverán los recoletos a la Isla de Negros hasta el 1848 en que, a instancias del prelado cebuano, se hicieron cargo de los curatos de Siaton, Cabancalan y Amblan.

Magnífica labor la llevada a cabo por los recoletos en esta región ${ }^{25}$. Desde el momento en que se hicieron cargo de aquel extenso territorio, pusieron todo su empeño en fomentar su riqueza, poniendo en juego todos los medios que estaban a su alcance para conseguirlo. Los que no conozcan la situación en que se hallaba la citada Isla de Negros a la llegada de los recoletos, nunca podrán formarse una idea aproximada del cambio tan radical que

23. Las biografias de estos dos últimos religiosos están escritas, la del primero en un grueso volumen, obra del mismo P. Minguella y la de este insigne escritor en el Catálogo del citado P. Sádaba.

24. Los agustinos de la provincia del Santísimo Nombre de Jesús predicaron también en Negros y por primera vez en 1580. Allí permanecieron hasta que, por falta de personal, cedieron la administración de los pueblos por ellos fundados al clero secular del obispado de Cebú. 
se operó en ella. Un testigo de excepción, el P. Pedro Sanz, se pregunta ¿qué era entonces la Isla de Negros? $Y$ contesta tajante: nada. Su rico suelo estaba en el mayor abandono; el filipino sembraba un poco de palay, maiz, camote..., en cantidad bastante a llenar sus necesidades para la vida; no existía por tanto agricultura, principal fomento hoy de riqueza de la localidad, y dicho se está que no podia haber industria y comercio; con lo que faltaba la vida al territorio que yacía sumido en la más escandalosa miseria. Pero llegaron los religiosos de San Agustín y enseguida se notó, el cambio. Dos años después de haberse posesionado de las tres primeras parroquias, el P. Provincial, Fray Antonio Ubeda, al dar cuenta al gobernador general del resultado de su visita por las islas Visayas, le decía que así como su corazón se hallaba algún tanto apenado al observar la pobreza y miseria de la provincia de Caraga, en Mindanao, debido al carácter insolente de sus moradores que sólo se mantienen de los muchos productos que la naturaleza les ofrece, sin que piensen en el trabajo y de ahí los grandes terrenos que se ven sin cultivar, otro tanto de contento y entusiasmo había recibido al recorrer la Isla de Negros, en la que no hay nada malo y que se considera la mejor del Archipiélago, que en los tres años que llevaban de administración sus súbditos había duplicado el número de tributos y que dado el gran porvenir que se espera en aquella isla, pensaba mandar muy pronto doce religiosos para que se fuesen haciendo cargo de algunos otros pueblos que estaban medio abandonados los unos, y los otros de nueva creación ${ }^{25}$.

Pasados algunos años más y con el aumento constante de misioneros, era tal y tan grande su progreso, que llamó la atención del mismo gobernador general, el cual, dirigiéndose a su vez al superior mayor de los recoletos en junio de 1853, le decía cómo al girar su visita al distrito de la Isla de Negros, le había sido sumamente satisfactorio adquirir el convencimiento práctico del distinguido y constante celo que los párrocos pertenecientes a la Orden de San Agustín demostraban por la prosperidad de los pueblos cuya cura de almas se les estaba confiado. Su verdadero y

25. Sobre la Isla de Negros y las misiones de los agustinos recoletos ha hecho un magnífico estudio -tesis doctoral- el P. Angel Martínez, tesis defendida en la Gregoriana y que mereció la máxima calificación en el verano de 1972.

26. PEDro SANz, Plan de Misiones de la Isla de Negros. Cit. en Sinopsis histórica, II, 122. 
bien entendido patriotismo en consorcio íntimo con su fe religiosa es la poderosa y verdadera palanca que conduce a los pueblos a sus adelantos morales y materiales, alegando para sus feligreses la suma más positiva de bienes y comodidades morales y materiales bajo la pura doctrina de Cristo y la protectora bandera española ${ }^{27}$.

La acción del misionero ha sido no sólo la salvaguardia de la fe, sino también y al mismo tiempo el agente más poderoso en lo que atañía a la prosperidad y bienestar de los pueblos. Muchos de los moradores de Negros vivian medio errantes y sin hogar fijo; y en una libertad semisalvaje que hacía huyeran a los bosques en cuanto la autoridad trataba de reducirles. Pues bien, el misionero se fue ganando poco a poco un respeto y una admiración que fue el primer paso para la aclimatación y vida sedentaria de los nativos. Por eso, la autoridad civil, conocedora de la fuerza moral del misionero, acudía siempre en casos como éste al superior mayor de las provincias religiosas para que cuanto antes se enviasen misioneros que redujesen a poblado a aquellas gentes acostumbradas a la vida errante y libre. A la sombra paternal del Cura se iba cobijando aquella gente más o menos montaraz, y aquel, poco a poco, con dulzura y mansedumbre les iba empadronando, con los que se les sujetaba a una vida más social, al mismo tiempo que se obtenía una gran ventaja para el Estado, o sea el aumento de tributos. Una vez reunidos en núcleos o poblados, el misionero les instruía no solamente en la religión cristiana, sino también en cuanto concernía al bien material, adelanto y progreso de los pueblos.

Mucho trabajaron los agustinos recoletos en el antiguo archipiélago de San Lázaro; pero bien podemos decir que su obra principal, al menos en los tiempos modernos, estuvo en esta Isla de Negros. $Y$ muchos fueron los pueblos administrados espiritualmente por ellos, en los que restauraron o levantaron de nueva planta iglesia, escuela y casa parroquial. Dumaguete, Bacong, Dauin, Zamboanguita, Sinton, en Negros Oriental; Nueva Valencia, Sibulan, Amblan y tantos otros ${ }^{28}$ fueron los pueblos donde la religión,

27. Ibid., 123.

28. La lista es larga y el número considerable; por 10 que renunciamos a su enumeración para no hacernos prolijos. 
la cultura, y el progreso de todo género avanzaron de modo considerable gracias al esfuerzo incansable de los misioneros.

Todavía tendremos que asistir a la nueva adquisición del colegio de Marcilla -antiguo convento del Císter, en este importante pueblo de Navarra - casa de formación de los futuros misioneros y donde hoy residen buen número de profesos. Posteriormente, la provincia de San Nicolás de Tolentino, en pleno auge, adquirirá un nuevo monasterio en San Millán de la Cogolla, el conocido por el nombre de "Monasterio de Suso", santificado por la presencia de aquel santo e insigne varón benedictino. A finales del siglo XIX, la misma provincia misionera contribuirá con sus religiosos a la restauración de la provincia hermana de la Candelaria, en Colombia, donde ha destacado, sobre todo, la figura insigne y venerable del citado arriba P. Ezequiel Moreno, obispo de Pasto. El P. Ezequiel es sin duda honra de la Orden y perla preciosísima de la mencionada provincia de San Nicolás de Tolentino.

En el ocaso de la soberanía española en Filipinas, cuando todo había terminado para nuestra nación, las corporaciones religiosas allí residentes y que habían sido fundadas precisamente para misionar en el Archipiélago, recibieron, como es natural, un duro golpe. De pronto, pasada la tormenta y después de pagar el caro tributo de sus mártires, como hemos de ver enseguida, estas corporaciones se encontraron con un copioso personal sin saber qué hacer con él, ni poder darle destino alguno, justamente porque toda su labor se tenía centrada en Filipinas. Fue entonces cuando se pudo comprobar el espíritu de que estaban dotados muchos de aquellos religiosos que pidieron marchar voluntariamente a América; con lo que se fue solucionando aquel grave conflicto que les había planteado la pérdida de las últimas colonias españolas. $Y$ fue así también cómo tuvieron comienzo las misiones agustinianas recoletas de Venezuela, fundadas en las postrimerías de 1898; misiones que supusieron el resurgir de la provincia, pues luego seguirían las fundaciones de Panamá y Brasil, con lo que tuvolugar la restauración de la provincia de Santo Tomás de Villanueva; con un brillante capítulo de las misiones en China a partir de 1906, si bien el primer grupo de misioneros no saldrían de Manila rumbo al celeste Imperio hasta el 11 de marzo de 1924, exactamente a la ciudad de Kueiteh-fu. 
Tal es, en breve sintesis, la gloriosa y bienhechora historia de la provincia misionera recoleta de San Nicolás de Tolentino.

\section{Los agustinos recoletos durante la revolución de Filipinas.}

La revolución de Filipinas no puede separarse de la cuestión religiosa. Filipinas, escribe el $P$. Licinio Ruiz, se conquistó para España por la Religión; vivió amparada por el manto protector de los religiosos, quienes se sucedieron unos a otros sin interrupción de cuatro siglos derramando sobre ella los inmensos actos de caridad que contiene el cristianismo, y a su sombra y bajo su protección se mantuvo fiel juntamente y al lado de la bandera española; y a ella y sólo a ella debe Filipinas el grado de civilización y cultura a que ha llegado ${ }^{29}$

En nuestro estudio LA PERSECUCION RELIGIOSA Y LA ORDEN DE SAN AGUSTIN EN LA INDEPENDENCIA DE FILIPINAS tratamos de aclarar ciertos puntos que pueden ser discutidos sobre: este asunto y las causas que le motivaron. No vamos a insistir sobre ellos y allí remitimos a nuestros lectores. Pero si queremos recalcar una vez más y en esto anda acertado el historiador recoleto, que las revoluciones, como todos los grandes hechos históricos, tiene su fundamento en una multitud de circunstancias y de hechos tan complejos e intrincados, que a nadie le es posible determinar y señalar cuál sea taxativamente el principal y decisivo que influyó en su realización, tanto más cuanto se trata de hechos como éste que no son obra de un día, sino que se viene elaborando en el decurso de los años, en cuyo lapso de tiempo son muchos y muy variados los agentes que obran sobre el mismo.

Concretándonos a los agustinos recoletos, diremos, con el $P$. Florencio Aranda ${ }^{30}$ que no era para nadie un secreto el cómo se había hecho, o llevado a efecto, la llamada paz de "Biac-nabató"; qué paz era aquella; cuánto duraría; el ánimo y aliento que había infundido, la forma en que se hizo en los principales autores, promovedores y cabecillas de la insurrección tagala, y los trabajos

29. LICINIo RUIz, o. c., II, 323.

30. Florencto ARANd, Prisión de los Recoletos en Negros, ms. compuesto por el mes de marzo de 1899 y conservado en el Archivo Provincial de Marcilla. 
más o menos solapados y encubiertos que éstos seguían haciendo, ya en la ciudad china de Hongkong los que acompañaron a Aguinaldo, y ya también en las provincias de Luzón, y aún en la misma Manila; los que quedaron acogidos al amplio y general indulto concedido por la primera autoridad del Archipiélago filipino, a pesar de las públicas protestas de arrepentimiento y olvido de lo pasado que todos dieron, y de la solemne promesa, casi juramento, que los mismos hicieron de adhesión a España y hasta de derramar toda la sangre de sus venas antes que volver a ofenderla y rebelarse otra vez contra tan noble nación que ha sido siempre para todos los filipinos una verdadera y cariñosa madre.

Que todo esto y mucho más prometían los cabecillas de insurrección lo prueba el Acta levantada el 26 de abril del año 1898 en la casa del Gobierno Civil de Manila con motivo de la guerra declarada entre España y los Estados Unidos. "En la Casa Gobierno de la ciudad de Manila - se dice allí- a 26 de abril de 1898, reunidos los que suscriben, convocados previamente por el Exmo. Sr. D. Pedro Alejandro Paterno, y bajo la presidencia del IImo. Sr. Gobernador Civil, acordaron espontáneamente presentar su condición de adhesión al gobierno de su Magestad al rey Alfonso XIII como hijos reconocidos de su clemencia y generosidad al otorgarle el perdón de sus pasados extravios, ofreciendo en su virtud, vidas y haciendas y también sus escasas influencias en defensa de nuestra común madre España". Y siguen las firmas de treinta y dos líderes que poco más tarde se harían famosos por su actividad revolucionaria.

El autor del manuscrito pasa luego a narrar los motivos que tuvieron los naturales para volverse contra los españoles, coincidiendo en todo con el criterio de otros testigos de los hechos e historiadores estudiados en nuestro trabajo arriba citado. $Y$ más adelante continúa: también sabíamos los residentes en la Isla de Negros las continuas, frecuentes e importantes deserciones que se observaban ya en el soldado o Guardia Civil visaya (hecho que rara vez sucedia antes), y lo apurado y contrariado que se hallaba el general Ríos en lloilo ante estas defecciones. Por lo que decidió trasladar a este último pueblo toda la fuerza disponible de Zamboanga y Mindanao y aceptar la colaboración de algunos moros armados de la misma zona.

Los religiosos que vivian en la parte norte y costa occidental 
de Negros apenas tuvieron un dia de tranquilidad desde el imponente levantamiento de Cebú, especialmente durante los meses de julio, agosto y septiembre de aquel 1898, pues en dichos meses los llamados agraviados del distrito de Concepción (Panay) que estaban muy cerca se paseaban por todos los pueblos del mismo quemando y destruyendo lo que les venía en gana, asesinando a españoles. e indígenas, y llegando su osadía a tal extremo "que anunciaban con anticipación a los pueblos y barrios el día y hasta la hora en que llegarían a los mismos".

Todos tenían conciencia de que las fuerzas con que contaba el citado general Ríos eran insuficientes para contener el incendio insurrecional y separatista del Panay y de Cebú. Lo más grave del caso era que todos los españoles tenían la plena seguridad de que no habrían de llegar de la Península los refuerzos que necesitaba Luzón y Visayas.

Esto tampoco era un secreto para los nativos de Negros y de otras partes. La propaganda nacionalista se hacía en aquella isla tan solapadamente que apenas llegaba a los párrocos y a los españoles en general, y siempre quedando bien encubiertos los principales jefes y cabecillas de aquel levantamiento.

Ante este panorama, uno se pregunta: ¿cómo, sabiendo todas estas cosas y conociendo el peligro que se cernía sobre la región de Negros, no trataron de ponerse a salvo los religiosos, diseminados en su mayor parte por distintas parroquias? El autor del manuscrito nos explica a este respecto: El general Ríos había telegrafiado varias veces al Gobierno español desde Iloilo, comunicándole que tanto en Visayas, como en Mindanao, reinaba una paz poco menos que "octaviana". Más tarde, se dio cuenta de su propio engaño, y prohibió a la prensa oficial hablar de la revolución filipina, o, en caso de hacerlo, quitarle importancia al asunto. De tal modo, que si alguna vez hablaban "El Porvenir de Visayas", "El Eco de Panay", o "El Heraldo" del movimiento insurrecional, era simplemente para calmar la opinión pública ya tensa y alarmada ante el avance de los insurrectos. También hablaban con elogio de las operaciones llevadas a cabo por el tan valiente y sufrido como escaso ejército español.

Por su parte, la secta masónica estaba lanzando una gran ofensiva contra los religiosos, de modo especial, contra los párrocos regulares. Hasta el extremo de que se llegó a dudar de su pa- 
triotismo, nunca desmentido y sí quizá en algunas ocasiones exagerado. La secta pedía "el todo por el todo", es decir, que como medida política se hacía ya necesaria la expulsión de los párrocos regulares, o séase, de los frailes.

Esta opinión era la que dominaba - sigue diciendo el manuscrito- entre nuestros compatriotas, con raras excepciones. Una de ellas era la del general Ríos el cual, lejos de poner en práctica la idea de los sectarios, participada por muchos españoles, así civiles como, principalmente, militares, llegó a prohibir a los recoletos que abandonaran sus respectivos puestos de trabajo, cosa que en ningún modo podía hacer y de lo que se lamenta el cronisnista ${ }^{31}$. Con tales prohibiciones, órdenes, trabas y cortapisas no hay para qué decir que se obligaba a los religiosos de Negros a ponerse "en las astas del toro", como vulgarmente se dice. Esto era lo último que faltaba, después de saber lo que ellos sabían respecto a aquella crítica situación en lo que se encontraban todos. Pero se quedaron y cumplieron como buenos. Conste, pues, dice el cronista inédito, que los cuarenta religiosos recoletos de Negros fueron hechos prisioneros por la única razón de quedarse en donde estaban por cumplir con su cargo y con una obediencia hasta última hora ${ }^{32}$.

31. El autor del relato cita dos casos que prueban hasta la saciedad to que acabamos de escribir. Un religioso recoleto, P. Blas Martínez, cura párroco de Azagra, al saber que en la cabecera del distrito habían entrado unos 400 tagalos, salló huyendo del pueblo, en compañia del P. Francisco Cabido, y, embarcados en una lancha vapora, propiedad del español Pedro Sanz, llegados que fueron a Iloilo, en vez de encontrar el refugio y hospitalidad que esperaban, recibieron la orden del general de Ia plaza, primero de no poner pie en tierra, y después, de volver a sus respectivos puestos de trabajo, pues alli no pasaba nada de particular y no existía peligro alguno.

El segundo hecho es más tajante todavia. Se trata de una orden dada por el general Ríos, en septiembre de aquel 1898, al señor Provisor de la diócesis de Jaro y al Sr. Gobernador de Negros, por la que prohibía terminantemente que los religiosos saliesen de la provincia sin licencia expresa del propio general, o cuando menos, sin el pase del gobernador, el cual no debia dar ninguno de no estar muy justificada la necesidad del religioso.

32. El P. Florencio Aranda, que escribe esta Memoria sobre los hechos más salientes que ocurrieron a los prisioneros de la Isla de Negros, insiste en que prefiere referir estos sucesos tal y como los mismos religiosos los relataron en notas que le fueron enviando con el fin de que no pierdan originalidad y frescura; debiendo, no obstante, advertir que bastantes de ellos, ya por modestia, ya por otros motivos, dejaron de narrar hechos muy importantes que presenciaron durante la prisión. 
III. Los recoletos de Negros, prisioneros del Katipunan.

La revolución filipina del 96 no había conseguido, a pesar de su empuje con que se manifestó en sus principios, propagarse y contagiar a las demás provincias del Archipiélago. Su esfera de acción ciñóse solamente a algunas provincias limítrofes de Manila; de ahí que fácilmente hubiese podido ser sofocada si en el gobierno español hubiera existido mayor alteza y miras y verdaderos deseos de apagarla.

El P. Licinio Ruiz aunque no atribuye a la masonería y al gobierno español las causas únicas de la revolución y todos los maies que trajo consigo para las misiones y las corporaciones religiosa, les acusa de haber sido los que principalmente prepararon el éxito de la insurrección, facilitando a los filibusteros todos los medios para que consiguieran su victoria. El gobierno español no supo, o mejor, no quiso vigilar e impedir aquellos movimientos revolucionarios y separatistas y después ya no pudo evitar las consecuencias de aquella organización que se había formado ante sus ojos sin protesta de ninguna clase ${ }^{33}$.

Porque sin duda que algunos, al menos de los que entonces formaban el gobierno presidido por don Práxedes Mateo de Sagas. ta, debían estar, y de hecho lo estaban, enterados de cuanto se tramaba y se hacía en Filipinas, y más todavía de ciertas negociaciones que tenian lugar entre los revolucionarios filibusteros y los Estados Unidos en América.

Tampoco era un secreto que muchos de los gobernantes de entonces formaban parte de la masonería española, y algunos con alta graduación, como el tristemente célebre Morayta. Sobre ese Gobierno, pues, y sobre la masonería española debe recaer el fallo de la justicia. Sean para ellos nuestras censuras -insiste el historiador-, no para otros elementos cuya actuación sólo ha merecido elogios ${ }^{34}$.

33. LICINIo RUIZ, Sinopsis..., II., 342

34. En nuestro estudio, citado al principio del trabajo, dejamos probado que, si bien es cierto cuanto dicen y escriben estos apologistas a ultranza de las Corporaciones Religiosas en Fillpinas, no todo fue tan sencillo como ellos lo explican, sino mucho más complicado y complejo, sin que podamos descartar alguna culpabilidad en las mismas y beneméritas Corporaciones Religiosas, aunque luego fueran tan perseguidas en sus miembros más esclarecidos. 
La revolución filipina del 98 se extendió rápidamente hasta los rincones más apartados del Archipiélago. Negros, la isla más progresiva, como los propios nativos la llamaban, no podía por menos de sumarse a las demás provincias insurrectas. En esta isla de $\mathrm{Ne}$ gros estaban lo mejor y el mayor número de misioneros recoletos. Estos misioneros, generalmente párrocos de otros tantos curatos, vivían confiados, pues sus feligreses permanecian al menos indiferentes a la marcha de los acontecimientos del país, a excepción de unos cuantos cabecillas que estaban en comunicación directa con los filibusteros de la capital. Las consecuencias de aquella confianza y extraña ignorancia de lo que se estaba tramando fueron catastróficas, pues al pronunciarse Negros el 5 de septiembre del citado 1898, cayeron prisioneros la mayor parte de los religiosos de aquella provincia, excepto algunos pocos que pudieron ponerse a salvo debido a circunstancias especiales.

Cuando los religiosos quisieron caer en la cuenta, se encontraron con los pueblos completamente sublevados y no pudieron hacer otra cosa que entregarse a la primera amenaza que les hizo el jefe de insurrección. El manuscrito que hemos utilizado para estos episodios ocupa 130 páginas en las que relata, con un detalle impresionante, hora a hora y minuto a minuto, la prisión de $40 \mathrm{mi}$ sioneros recoletos. Ya puede suponerse el lector que no nos vamos a entretener transcribiendo estos relatos de cada religioso que sufrió persecución, aunque reconocemos que contiene anécdotas y cosas interesantes, sobre todo, la conducta seguida por muchos nativos al tiempo de las despedidas o al paso por los distintos poblados.

Los cuarenta religiosos recoletos fueron enviados a la cárcel de Bacolod, penal construido el 1890, en tiempo y por mandato del ilustre general D. Valeriano Weiler y durante el mando como gobernador de aquella provincia de don Camilo Lasala, con la activa, directa y desinteresada colaboración del P. Mauricio Fresno, cura párroco de aquella cabecera, y con maderas que proporcionó el $P$. Julián Ubernaga, misionero entonces de Inayanan.

El P. Florencio Aranda, uno más entre los prisioneros, se detiene y deleita en la descripción del edificio, y luego nos dice a propósito del primer "alcayde" o gobernador de la cárcel lo que sigue: "El alcayde primero a quien tuvimos por jefe los padres prisioneros por espacio de dos meses, a juzgar por sus hechos y di- 
chos, no diré ni afirmaré yo que fuera un tirano, como quieren algunos; ni un verdugo, como creen otros; si a los adjetivos se les ha de dar la acepción y significación estricta y propia que indican las mismas palabras". El cronista trata, pues, de ser imparcial y veraz. Por eso, el calificativo que mejor le cuadraba era el de "alcayde digno de un gobierno revolucionario"; un hombre lleno de prejuicios contra los religiosos y contra la misma religión católica; alucinado y dirigido por la secta masónica. El fue quien dispuso que se preparase el calabozo más oscuro, "asqueroso e inmundo" para los religiosos, habiendo sacado del mismo a un grupo de criminales caracterizados y señalados en la zona. $Y$ a este hombre se refieren aquéllos cuando dicen en sus relatos que les insultaba, calumniaba, denigraba y profería palabras soeces contra la religión católica. Este hombre es el famoso jefe de la cárcel de Bacolod que, al tiempo de ingresar los prisioneros del Katipunan, mandaba registrar sus maletas y se incautaba de cuanto encontrara en ellas de algún valor. El mismo que prohibió a los vecinos de la mencionada ciudad visitaran a los religiosos, amenazando con duros castigos a las familias que se atrevieran a acercarse a ellos con algún regalo, o siquiera con el fin caritativo de hacerles más llevadero su cautiverio. Este es aquel pillastre - la palabra la recogemos del manuscrito- que llamaba a los sufridos frailes a su despacho, les obligaba a escribir cartas a personas amigas pidiéndoles dinero para socorrer sus primeras necesidades, y una vez que el dinero llegaba a la cárcel, se quedaba con todo, vengándo. se de los que se negaban a aquella acción ${ }^{35}$.

Muy mal debieron pasarlo en aquel calabozo ${ }^{36}$, y mucho tu-

35. No es cuestión de seguir relatando pormenores. Se repiten y se suponen. Por ejemplo, el obligar a los religiosos a limpiar los excusados de la cárcel, y llevar las basuras de la misma al mar por medio de la calle principal y a la hora punta en que más gente pululaba por ella. Lo que sí hacemos constar es que el $P$. Aranda insiste, una y otra vez, en que el relato se queda corto, tratando de ser "imparcial y sereno", y callándose por prudencia cosas que no deben decir en públíco. Es más, reconoce que hubo días del mes de diciembre y enero en que el mencionado alcayde les concedió "bastante expansión por el interior de la cárcel"; en otras ocasiones, se compadeció de la triste situación en que se hallaban los religiosos y elogiaba la paciencia de muchos de ellos. Todo lo cual prueba, por un lado, el carácter voluble de aquel personaje, y por otro, los compromisos que debía tener con "los jefes de mandil" que le habian dado aquel cargo con el grado y empleo de teniente coronel del ejército filipino. (Ms. fol. 161).

36. El $\mathrm{ms}$. inserta dibujos hechos a lápiz de las celdas y enseres de los mismos y hasta de objetos de suplicio. 
vieron que sufrir los recoletos en Bacolod. Incomunicados de las gentes sencillas y buenas, que seguian queriendo y estimando a: los misioneros, como si fueran criminales; visitados solamente por oficiales que delante de ellos hacian ostentación "de sable y revólver"; insultados con palabras groseras cuando los sacaban a los patios; mal alimentados. ${ }^{37}$; siempre vestidos con la ropa: que llevaron a la prisión; amontonados en míseras celdas, sin asiento alguno ${ }^{\text {:8; }}$ sin servicios de higiene; teniendo que colocar los hábitos a la entrada y en las mismas ventanuchas como mosquiteros; durmiendo en catres viejos y sobre nipas que hacian de colchonetas ${ }^{39}$... Así, hasta el 18 de enero de 1899 en que recibieron una orden superior de evacuar aquel triste lugar, Bacolod, y encaminarse a la llamada "Granja Modelo". Los frailes recoletos, acompañados de un grupo de guardianes ${ }^{40}$ de la misma prisión, salieron del penal por la tarde del día citado, llevando consigo por todo equipaje un pequeño envoltorio que les permitieron hacer con la manta de dormir ${ }^{41}$, y teniendo que hacer todo el trayecto a pie, o como dice con cierta gracia el autor del manuscrito, "pedibus andando" hacia el sur de la provincia.

Eran 35 los religiosos y algunos de ellos iban enfermos de alguna gravedad. El pueblo de Bacolod quedó hondamente impresionado ante el espectáculo que ofrecían, y fueron muchas las lágrimas que corrieron de los mejores ciudadanos en aquella hora desdichada ${ }^{42}$. De esta guisa y sin atreverse a pronunciar una palabra,

37. Da verdadera grima leer "el menú" de cada día y, al mismo tiempo, causa admiración el aguante y la bondad de nuestros prisioneros.

38. El cronista llega a decir que los religiosos tuvieron que arrancar las maderas del balcón para colocarlas encima de unos ladrillos y, de este modo, tener donde sentarse.

39. El P. Florencio, haciendo gala de narrador y literato, se hace acompañar de un supuesto amigo, y con gracia, no exenta de suave ironía, va mostrándole todo cuanto pueden encontrar en aquella odiosa mansión, y le cuenta, al mismo tiempo, la vida que llevaban en ella. los prisioneros del Katipunan (Ms., fol. 185-198).

40. Este cuerpo de guardias de la cárcel estaba compuesto por los presos del mismo penal, a los que el gobierno revolucionario acababa de poner en libertad, y algunos de los cuales eran reos de tres y hasta de cuatro asesinatos (Ms., fol. 199).

41. Manta de dormir, que no todos tenian.

42. El autor del relato cuenta que él mismo percibió muy clara y distintamente los lamentos que salían de la casa de un capitán indígena, el cual aconsejaba a su hija a que callase, pues iba a comprometer con sus gritos y su llanto a toda la familia. Pero la joven se recriminaba que eran ellos - los nativos- los culpables de aquella situación y los responsables del fin que esperaba a los pacientes prisioneros. 
atravesaron, descalzos como iban, los ríos Pasip y Massingay. En marcha todavía, ignorando la meta de su nuevo destino, se atrevieron a pedir al Cabo que iba como jefe de custodia les concediese alguna pequeña expansión y descanso, pues estaban agotados, sobre todo los que iban enfermos y con calentura. A lo que el hombre se avino cargando sobre sus hombros toda responsabilidad. Esta conducta del cabo San José, que así se llamaba el bondadoso oficial, se completó con la de un vendedor de cerveza ${ }^{43}$, al que encontraron de camino y que les invitó a tomar cuanta quisieran, pues iban, más que sedientos, deshidratados. Más adelante, salieron nativos al encuentro de la caravana y se ofrecieron voluntarios para llevar los envoltorios de los religiosos enfermos; y aún un carretero, con su carro se ofreció generosamente para transportarlos.

Llegados al pueblo de Sumag al caer de la tarde, fueron conducidos al convento que en él había, donde descansaron, cenaron una "ración de morisqueła morena con pollo y pescado", y cada cual se buscó un lugar retirado para el reposo que bien lo habían ganado ${ }^{44}$. Al día siguiente, muy de mañana, recibieron la orden de emprender de nuevo la marcha de la misma forma en que llegaron, es decir, los enfermos montados en carros y los sanos a pie. Al tiempo de atravesar el río Calumngan, los de a pie lo hicieron a través de un puente de cañas y los carros fueron transportados en balsas. En Bago, pueblo inmediato de camino, no encontraron la buena acogida del anterior. El jefe del gobierno revolucionario ${ }^{45}$ había prohibido bajo severas amenazas toda manifestación de afecto o simpatía hacia los prisioneros; de modo que las calles aparecían ahora desiertas y los nativos, al ver la caravana, echaban a correr y se escondían en sus casas. Momentos anies de lle-

43. Es curioso cómo en la Memoria se nos ofrece hasta la marca de la misma. (Ms., fol. 204).

44. Como nota también curiosa hemos de destacar que en este lugar se presentó el hermano de uno de los religiosos gravemente enfermo con orden del gobierno revolucionario para llevárselo de nuevo a Bacolod; pero, al saberlo aquél, se negó a abandonar a sus compañeros, queriendo seguir su misma suerte hasta el final. La consideración moral que, al llegar a este punto, hace el cronista se la perdonamos al inteligente lector.

45. Además de este jefe de poblado, que era a la vez delegado de guerra, habia, según testimonio unánime de españoles y filipinos, otro que era como el principal, mestizo él, y que llevaba sangre española, presidente a la sazón del "Congreso de Diputados". (Conf., Ms., fol. 211). 
gar a la plaza del pueblo, se detuvieron y formaron de dos en dos ${ }^{46}$. El que hacía de jefe saludó respetuosamente a los prisioneros y les obsequió por todo desayuno con una lata de sardinas, dos diminutos panecillos para cada uno y la clásica cerveza que ya habian gustado por el camino.

De gana salieron de aquel pueblo que tan friamente les había recibido ${ }^{47}$; y de buena gana recibieron también el aumento de escolta armada, pues lo mismo les daba diez que diez mil. Lo que de verdad deseaban era llegar cuanto antes al término de su peregrinación. Cruzaron en balsas el anchuroso rio Bago ${ }^{48}$, no sin que parte de la travesía la hicieran a pie ${ }^{49}$, para ganar tiempo, según decian, y prosiguieron hasta el inmediato pueblo de Valladolid, donde los vecinos se volcaron sobre ellos, sin que lo impidiesen esta vez, con obsequios y atenciones. También aquí hubo "morisqueta morena", con guisos de carne y pescado, hecho al estilo del país, si bien tuvieron que aceptar de buen grado por toda mesa y mantel el santo suelo. Incluso, todo hay que decirlo, les ofrecieron café o té, a gusto del consumidor.

Y otra vez en marcha, camino del pueblo de San Enrique, donde se repitieron iguales o parecidas escenas por parte de la vecindad. $Y$ otro rio que vadear, y el desencanto de Candaguit, en donde ya no les dieron ni cena ni lugar de alojamiento para el descanso de la noche. Esta vez les falló hasta el elegante y bondadoso cabo San José ${ }^{50}$. De nuevo pedimos excusas al lector por no transcribir la consideración moral que hace el autor del manuscrito, el cual no sale de su asombro ante la conducta seguida por

46. Esta forma de entrar en los pueblos obedecia a órdenes dadas a los tiradores en Bacolod, ya que se cumplió indefectiblemente en todos, a no ser que llegaran de noche, pues en este caso no había lugar. (Ms., fol. 212).

47. Sgún testimonio del cronista cautivo y viajero, éste fue el único pueblo en que nadie se dignó acercarse al alojamiento de los prisioneros; $y$ en aquel tribunal no vieron otras personas que soldados, oficiales y jefes revolucionarios.

48. El P. Aranda dice de él que, "mejor que rio, debería llamarse brazo de mar por la anchura que tiene".

49. Resulta curioso observar el buen talante y hasta la risa que daba a nuestros religiosos viéndose unos a otros mojados hasta la más de la cintura y con un aspecto verdaderamente grotesco.

50. Decimos esto, porque los religiosos esperaban de él que consiguiera del jefe siquiera unas horas de descanso para los maltrechos prisioneros. Pero falló y no hubo lugar a ello, siendo así que lo necesitaban más que el comer. 
aquellos señores ${ }^{51}$ en cuya propiedad estaban alojados, máxime, cuando contaban con tantos amigos entre los mismos religiosos.

Pero sigamos el lento paso de los carros, con su sufrida carga, cruzando ríos y consiguiendo pequeñas y esperanzadoras metas de poblados. En La Carlota pasaron "una noche de agonía", en frase gráfica del narrador ${ }^{52}$, entre amenazas de muerte y soportando anticipadamente con la imaginación los horrendos suplicios que de soldado a soldado se gritaban para que lo oyesen hasta los más sordos. La hora de la "matanza" sería sobre las dos de la madrugada, el golpe simultáneo y allí mismo en la sala en que se encontraban amontonados los prisioneros. Estos quisieron tomarlo a broma, pero el miedo es libre y sabian, por otra parte, que aquellos insurrectos eran capaces de todo. Pero pasó la hora señalada para "el degüello de los inocentes". ${ }^{53}$ y como premic por lo valientes que habian sido, fueron obsequiados con un espléndido desuyuno ${ }^{54}$.

Por fin, llegaron a la granja, propiedad del gobernador español, incautada por las fuerzas revolucionarias. Un mestizo, Francisco Pérez, la dirigía. Los prisioneros fueron alojados en el local destinado para almacén de azúcar, donde esperaron acontecimientos. Se siguieron las visitas del nuevo jefe y los malos tra-

51. Eran los señores Trías y Locsín.

52. La nota no deja de ofrecer su gracia. Apenas vieron los centinelas acostados a todos los religiosos, empezaron a tocar el pito, con intervalos de un minuto. Las pitadas que daba el centinela, que estaba en un lugar próximo a la sala, eran repetidas por otros dos situados, uno en los bajos del convento y otro en la calle a corta distancia. Además, otro de los insurrectos se colocó debajo de la misma sala, no cesando de canturrear en toda la noche. Por si esto fuera poco, el oficial de vela daba ordenes a cada momento del tenor siguiente: "ipreparad las cuerdas!... ique ivengan veinte soldados más al convento!... ipreparad en una lata sal y vinagre!..." $Y$ cosas por el estilo. (Ms., 233).

53. El autor del relato nos dice en nota expresiva que vio las cosas y todo lo que le rodeaba de tan mal cariz, que tomó la resolución de desabrocharse el cuello de la camisa "y arremangarse hacia abajo-literal-, con el fin de que el verdugo no tuviese necesidad de dar más que un solo golpe ; de sable, suficiente para cortarle la cabeza. (Ms., fol. 242).

54. Con buen humor y gracia nos dice el cronista que consistió en "un recipiente mugriento $y$ asqueroso de caña conteniendo morisqueta negra con mucho palay, todavia por pilar y moler, y una lata de petróleo, llena de mugre por dentro y por fuera que contenía calabaza cocida, sin pelar ni limpiar todavia. Pero como quiera que "al hambre no hay pan duro", los religiosos lo tomaron y siguieron su pequeño calvario, no sin recibir visitas impertinentes $y$ molestias de personas extrañas y desconocidas. 
tos $^{55}$, añadiéndose los trabajos forzados en el campo. Así las cosas, el día primero de febrero se recibió una orden, que traía un piquete de tiradores, de recoger los presos y llevarlos de nuevo al punto de partida, es decir, al pueblo de Bacolod. A decir verdad, la noticia produjo de pronto en los religiosos el mismo efecto que produce un jarro de agua fría echada de improviso en el que está tranquilamente dormido. Luego se alegraron y se resignaron a lo peor. El camino de regreso y los pueblos a recorrer eran de sobra conocidos. La noticia corrió como reguero de pólvora y los vecinos de La Carlota y de Candaguit se disputaron el honor de agasajar a los buenos religiosos ${ }^{56}$. Mas para que hubiera de todo en la viña del Señor, cuando apelaron a la caridad de un carretero que encontraron camino de San Enrique para que llevase sus bultos hasta el pueblo, éste se negó excùsándose que tenía mucha prisa ${ }^{57}$. Llegados al citado puebló se hospedaron de nuevo en el convento el preciso tiempo para comer y reponer fuerzas, pues había que proseguir la marcha enseguida hacia Valladolid.

No les dieron tiempo de descansar. Las órdenes que recibia cada poco el oficial que comandaba el piquete eran tajantes: "en cualquier punto en que os encontreis con los prisioneros, continuad la marcha hacia Bacolod, sin deteneros a dormir en ninguna parte". Con la llegada a la capital de provincia, había terminado el vieje de regreso. El encuentro y consiguiente diálogo con el delegado de Guerra, señor Araneta, fue breve: comoquiera que los prisioneros no habian pedido nada; y comoquiera también que el gobierno español no se había dirigido al revolucionario solicitando la libertad de sus súbditos, aquel, en nombre del gobierno de su provincia, se la concedía. Solamente les pidió que firmaran por duplicado el Acta de libertad y que cuando llegaran a lloilo publicaran un suelto en el periódico elogiando la conducta seguida por el jefe y delegado de insurrección, desmintiendo con esto la noticia que había aparecido en un diario de la citada ciudad de

55. Como el aposento aquel era tan pequeño para los 34 religiosos, tuvieron que colocarlos para dormir en la misma forma - y valga la comparación - con que se colocan las sardinas de cubo: todos muy juntos, las cabezas arrimadas a la pared, formando los cuerpos un ángulo recto con aquellas. (Ms., fol. 259).

56. El ms. trae en nota el nombre de varias personas que se signifcaron por su caridad hacia los prisioneros.

57. No le quedó más remedío que hacer de guía y llevar los paquetes de los prisioneros en su carro cuando el oficial de escolta le amenazó con las armas si no cumplía con aquel menester. 
cómo los religiosos habían sido maltratados y obligados a trabajar en faenas agrícolas durante su estancia en la granja.

¿Qué inconveniente habían de tener los prisioneros -comenta uno de ellos-en firmar todo lo que quisiese el gobernador revolucionario? ¿Acaso nos consideraba el señor Araneta con la libertad que se requiere para afirmar un documento de aquella especie? ¿Por ventura no sabíamos muy bien nosotros que con la misma facilidad con que se nos había dicho: "quedan ustedes libres", se nos podía decir después: "siguen ustedes en la prisión", de no haber accedido a lo que se nos mandaba en tono de súplica? ${ }^{58}$. Creemos que no le faltaba razón a nuestro prisionero. Porque, como dirá en otra parte, ¿qué libertad era aquella que despojaba a los religiosos de sus parroquias y les obligaba a salir fuera de ellas?...

El espectáculo que ofrecía la playa de Bacolod al tiempo de embarcar los excautivos de la revolución era conmovedor. Treinta y siete religiosos sacerdotes ${ }^{59}$ abandonaban la Isla de $\mathrm{Ne}$ gros, cultivada con tantos sudores, sacrificios y esmero ${ }^{60}$. Embarcaron en el vapor "Monserrat" y llegaron sin novedad a lloilo. Una lancha americana se acercó al barco español y dos oficiales, acompañados de intérpretes, saltaron a bordo para saludar a los pasajeros y registrar el cargamento del navío. De todos los prisioneros solamente tres saltaron a tierra. La mala suerte quiso que se encontrara en la citada ciudad de lloilo el presidente del gobierno insurrecto de Negros, el cual había llevado consigo varias cartas escritas por religiosos que comprometían a una empresa, a la que pedían cierta cantidad de dinero mientras estaban en la cárcel. Quería aprovechar la circunstancia de la venida de los recoletos para hacer efectivas dichas caniidades, so pena de quedar nuevamente detenidos y no poder seguir viaje a Manila.

¿Qué hacer?... Creemos que nosotros tampoco lo hubiéramos dudado mucho tiempo. Pero ya se ve a qué precio concedían la libertad aquellos hombres de la revolución y cuán cara les resultaba a los agustinos el recobrarla. Amaneció el 4 de febrero de

58. Ms., fol. 324 .

59. A los 34 que estuvieron en la granja, se agregaron tres más el día del embarque.

60. Arriba queda anotado cómo la evangelización de la Isla de Negros se puede decir que fue obra casi exclusiva de los agustinos recoletos. 
1899. Nuestros prisioneros desayunaron tranquilos y transbordaron al vapor inglés "Libelle". El 7 del mismo mes se encontraban, por fin, en Manila. Era la hora de la verdadera y ansiada libertad.

\section{Victimas de la revolución en Cavite}

Lo primero que sorprende leyendo el "Libro de Difuntos" existente en el Aychivo Provincial de los agustinos recoletos de Marcilla y que comienza con el año 1889 es el número de víctimas de la insurrección de 1896. Aun habiéndose descubierto con alguna antelación y antes de que los filibusteros se lanzaran al campo, la conspiración, abortada y todo, produjo muchos estragos. El cronista, al tiempo de sopesar y juzgar las graves consecuencias, compara este movimiento revolucionario a los grandes cataclismos y violentas conmociones, de tiempo en tiempo, se dejaban sentir en Filipinas; y el carácter que reviste le asemejan en un todo a las más horribles hecatombes que, sepultando vastos imperios y destruyendo naciones enteras, anegaron en sangre ciudades, pueblos y aldeas. Sin embargo, cauto y prudente, no se atreve a emitir un juicio definitivo porque, para poder hacerlo con éxito, se requeriría "que el ánimo gozase de la serenidad tan necesaria no sólo al crítico que juzga fríamente y trata de relacionar entre sí los acontecimientos y éstos con las causas que los produjeron, sino también el simple historiador que debe relatar con toda imparcialidad y libre de toda preocupación y apasionamiento los hechos, pintándolos con su natural colorido ${ }^{61}$. Pero esta serenidad - confiesa el autor del Libro de Difuntos- hoy por hoy no existe, por hallarse la insurrección en su momento álgido y estar todos sumidos en terrible y angustiosa incertidumbre sobre el desenlace de la misma. Es más, el cronista se pone a escribir las necrologías de las víctimas de Cavite a sabiendas de que le faltan muchos datos por conocer. Pero estos datos quedan para que, si vale la pena, se consignen más tarde en la Historia General de la Orden ${ }^{62}$. Las noticias son, pues, de primera mano, inéditas y tomadas en los mismos ins-

61. Libro de Difuntos, fol $52 \mathrm{v}$.

62. Efectivamente, estos datos serán aprovechados por el Francisco Sádaba para su Catálogo y por el historiador $P$. Licinio Ruiz para su Sinopsis histórica de la provincia recoleta de San Nicolás de Tolentino. 
tantes de la revolución caviteña de 1896 que terminaría, como sabemos, con la frágil y engañosa "Paz de Biacna-bató".

a) José $M^{a}$. Leante del Carmen. Era natural de Tudela, Navarra, y había nacido el 18 de diciembre de 1831. Tomó el hábito de agustino recoleto en el colegio de Monteagudo el 16 de septiembre de 1848, profesando el 17 del mismo mes del año siguiente. Terminados sus estudios, pasó a Filipinas el año de 1852. Ordenado de diácono en el 1854 y al año siguiente de sacerdote, fue destinado al pueblo de Yba, en Zambales.

En el capítulo Provincial de 1864 fue nombrado vicerrector del colegio citado de Monteagudo. Pero regresaría muy pronto a las misiones, ejerciendo la cura de almas en distintos pueblos del Archipiélago. Hasta que en el Capítulo Provincial de 1873 fue elegido provincial.

Estando de superior mayor el P. Learte, tuvo lugar la famosa expedición militar a Joló, organizada por el general Malcampo. Seis religiosos recoletos fueron designados como capellanes de la misma ${ }^{63}$. El P. Learte, además de enviar a estos seis religiosos en calidad de capellanes, ofreció la cantidad de 1.000 pesos para subvenir los gastos de la campaña. Ni que decir tiene que el general Malcampo agradeció en lo que valía aquel gesto de generosidad dando cuenta del mismo al gobierno de Madrid.

Terminado el provincialato, volvió a ser aquel simple párroco que él siempre había deseado y trabajó con gran celo en la provincia de Zambales ${ }^{64}$. En todos cuantos cargos ejerció, sobre todo en la cura de almas, se distinguió por su amabilidad de carácter y verdadero celo apostólico, con el que trabajó sin cesar, ya con sus consejos y predicación, ya editando libros de piedad, como el "Catecismo" en lengua zambaleña, el "Reglamento de la Corte de María Santísima" y las traducciones a dicha lengua de los "Ejercicios de San Ignacio" y el "Anuario de María". Así escribió el autor de la historia de los recoletos en Filipinas. $Y$ el $P$. Sádaba, en su

63. He aqui los nombres de aquellos religiosos agustinos: Toribio Minguella, Vicario provincial y cura párroco-foráneo de Cavite, más tarde Comisario en Madrid y finalmente obispo de Puerto Rico; Gregorio Bueno, cura de Mabalacat; Toribio Bonel, cura de Caloacan; Félix Melero, cura de Moring; Félix Garcés, cura del pueblo de Lobo; Ramón Zueco, Vicario provincial y foráneo de Misaniz. (Libro de Difuntos. fol. 56).

64. Siendo todavía superior mayor, promovió las misiones de Inayanan, San Sebastián, Bayanan y Tolon, en la Isla de Negros. 
catálogo, dice del P. Learte que ha dejado entre sus hermanos fama de santo, justamente adquirida con sus excelentes virtudes y vida ejemplarísima, pues tanto de súbdito como de prelado, fue siempre modelo de observancia regular y de perfección religiosa ${ }^{65}$.

b) Simeón Marín, del Amor Hermoso. Natural de Cornago, Logroño, donde vio la luz primera el 21 de febrero de 1849. Tomó el hábito de agustino recoleto y profesó en el convento de Monteagudo a la edad de 15 y 16 años respectivamente. Llegó a Filipinas el año de 1870. Se ordenó de sacerdote en marzo de 1872. Impuesto en el idioma tagalo, fue nombrado Cura interino de Naujan, en Mindoro. Más tarde fue prior del convento de Cavite. Definidor en 1888. Se encontraba en Maragondon, de Cavite, cuando se inició la insurrección filipina de 1896.

El autor del Catálogo, que se detiene en el detalle de los distintos curatos que regentó en Filipinas, termina su breve biografía diciéndonos que el estallar la insurrección tagala, hallábase en el pueblo citado, parroquia de Maragondon, donde sucumbió al furor de las hordas lanzadas al campo por los jefes del Katipunan ${ }^{66}$. El P. Licinio Ruiz completa el apunte biográfico diciéndonos que su muerte acaeció durante el mes de septiembre del citado 1896.

c) Toribio Mateo del Carmen. Nacido en la ciudad de Corellas, Navarra, el 16 de abril de 1846, profesó en el colegio de Monteagudo el 24 de mayo de 1864. Pasó a Filipinas en junio de 1868, a bordo de la fragata "Reina de los Angeles". Se ordenó de sacerdote el 1869. Fue destinado a la parroquia de Morong, en la provincia de Cavite. Más tarde administró varios curatos. Cuando surgió la insurrección en Cavite estaba de residencia en el pueblo de Pérez - Dasmariñas.

El cronista nos cuenta que, reunido este excelente misionero con los Hermanos de Obediencia Luis Garbayo del Carmen y Julián Umbón del Corazón de Jesús que cuidaban la casa de Salitrán, situada cerca de la hacienda de Imus, se dirigieron juntos hacia el pueblo de Silang, medio escondidos, para pasar inadvertidos de la gente. Pero pronto, al entrar en el barrio de Sampalok, se encontraron inesperadamente con una partida de revolucionarios que

65. Francisco Sadaba, o. c., 354 .

66. Ibld., 546-47. 
venian de Imus y sin darles tiempo más que a recibir los hermanos la absolución del padre, los tres cayeron acribillados a balazos, siendo enterrados en el mismo barrio de Sampalok ${ }^{67}$.

d) Agapito Echegoyen de San José. Era natural de Olite, Navarra, donde vio la luz primera el 24 de marzo de 1850. Llamado al estado religioso, profesó en el citado colegio de Monteagudo el 29 de julio de 1868, pasando a Filipinas el año 1872. Se ordenó de sacerdote en Manila e inmediatamente fue destinado como compañero del Cura párroco de Castellejos. Administró varias parroquias; hasta que en 1887 le vemos en la parroquia de Amadeo, donde le sorprendió la revolución. Hecho prisionero, padeció lo indecible, hasta que en el mes de abril de 1897 murió a manos de los insurrectos junto con los padres Piernaveja, Domingo Candenas y Hno. Matías Rivero, los tres agustinos calzados de la provincia de Filipinas.

El autor de la relación de las víctimas de Cavite - Fray Andrés Ferrero de San José-, al referirse al P. Echogoyen nos dice, ingenuamente, lo siguiente: "Acerca de este religioso han corrido rumores de que no había muerto, sino que le tenían cautivo los rebeldes y así lo hizo constar el P. Provincial en la circular del 20 de octubre, en la cual consignaba la nómina de los religiosos que echábamos de menos en la provincia de Cavite... No obstante, como al cabo de más de tres meses que han transcurrido no se ha tenido noticia alguna, creemos debe ser incluído en esta relación como una de las víctimas causadas por indios levantados en armas contra la madre Patria ${ }^{68}$. Y a renglón seguido, pone una adición en la que da cuenta de los muchos sufrimientos y de la muerte del biografiado en compañia de los hermanos agustinos calzados nombrados arriba ${ }^{69}$.

e) Faustino Zizasoain de San Roque. Natural de Cabanillas, provincia de Navarra, vino al mundo el 15 de febrero de 1855. Como los religiosos anteriormente citados y todos los de esta época, profesó en el citado colegio de Monteagudo en 1872. Llegó a Fili-

67. LICINIo RUIz, o. c., II., 352-3; Libro de Difuntos ,fol. 57.

68. Libro de Difuntos, fol. $58 \mathrm{~g} \mathrm{v}$.

69. LICINIo RUIZ, o. C., 359-60.- En nuestro estudio, La persecución religiosa..., dimos detallada cuenta de los personajes a que se alude en este lugar. Allí remitimos a nuestros lectores, p. 189 ss. 
pinas por el mes de enero de 1878. Se ordenó de sacerdote en Manila al siguiente año, y enseguida le enviaron al pueblo de Silang para aprender el tagalo, primera tarea que tenían que hacer los jóvenes misioneros enviados desde la Metrópoli. Desde el 1880 administró varias parroquias. La revolución lè sorprendió en la de Bailén, de la provincia de Cavite, y allí fue asesinado por los insurrectos en los primeros días de septiembre de 1896.

El historiador Licinio Ruiz y el autor del Catálogo, P. Sádaba, no dan otras noticias que las añotadas arriba. Pero el encargado de hacer el Necrologio, existente en el Archivo de Marcilla, dice de este religioso que al enterarse de lo que ocurría en la provincia de Cavite, se fue al pueblo de Alfonso donde había un piquete de la Guardia Civil, en cuyo cuartel se estuvo defendiendo de los rebeldes que a todo trance trataron de tomar aquella posesión y apoderarse de las armas en ella almacenadas; lo que, al fin conseguirían, muriendo en la refriega el Cabo que mandaba el piquete y el $P$. Faustino que se resistió hasta el último aliento ${ }^{70}$.

f) Toribio Moreno de la Soledad. Había nacido en Cornago, Logroño, el 11 de noviembre de 1857; y profesado en el célebre monasterio de Monteagudo el 13 de septiembre de 1875. Arribó al archipiélago filipino en la misión que salió de Barcelona el 25 de octubre de 1880 en el vapor "Reina Mercedes". Ordenado de sacerdote dos años más tarde, fue destinado al seminario de Vigan como profesor. En 1889 le nombraron administrador de la hacienda de San Juan de Imus. En el mes de septiembre del año siguiente le vemos de subprior y maestro de novicios en Manila. Poco después le eligieron para vice-rrector del colegio de Marcilla, cargo que no quiso aceptar. Volvió entonces a las parroquias de Carmona y Silang, donde le cogió de improviso la insurrección del 1896.

La relación manuscrita nos cuenta que, habiendo sido advertido el $\mathrm{P}$. Toribio del peligro que corría en Silang por un cristiano fiel y de toda confianza ${ }^{71}$, se negó a huir, como le aconsejaba incluso el mismo capitán del municipio, por nombre Lázaro, un hombre al parecer de buenos sentimientos, pero en aquella ocasión traidor y descubridor del paradero del religioso. El hecho es que

70. Libro de Difuntos, fol. 59 y s.- F. SADABA, o. c., 605.- L. RuIz, o. c., II, 360 .

71. Se llamaba José Gana y había ejercido el cargo de primer Teniente en Silang por los años 1891-92. 
al amanecer del día 4 de septiembre del aquel nefasto 1896 llegaron al lugar donde se había refugiado el $P$. Toribio un grupo de foragidos, al frente del cual iba el mencionado capitán municipal. Aquellos hombres amarraron al misionero y lo condujeron maniatado hasta un barranco que habia frente al convento. Uno de ellos, el único que llevaba arma de fuego, disparó contra él por la espalda ${ }^{72}$.

g) Juan Herreiro del Amor Hermoso. Nació en Arnedo, provincia de Logroño, el 16 de mayo de 1862. Profesó en Monteagudo el 17 de junio de 1878. Pasó a Filipinas en la barcada de 1882. Como la mayor parte de sus compañeros, ejerció la cura de almas en distintas parroquias ${ }^{*}$, hasta que, conociendo los superiores sus excelentes dotes, le colocaron al frente de la hacienda de Imus, cargo para el que se requería un tacto especial y una prudencia exquisita. Esto ocurría el 1891. Luego que estalló la insurrección en las cercanías de Manila, el P. Provincial le escribió una carta diciéndole que, en vista del mal cariz que estaban tomando las cosas, hiciera lo que su prudencia le dictara como más acertado.

EI P. Herrero consultó con el párroco del lugar, que no era otro que el ya conocido P. Learte; y los dos convinieron en que se imponía una mayor vigilancia, pero que el peligro no era tan grave como para abandonar la hacienda. Así se lo hizo ver a los Hnos. de Obediencia que estaban con él al cuidado de la finca y todos esperaron serenos los acontecimientos.

Así las cosas, el día primero de septiembre se levantaron los insurrectos en Imus. La Guardia Civil pudo hacer frente, pero necesitaba de refuerzos. El P. Herrero envió un despacho urgente reclamándolos; mas, éstos, como en tantas ocasiones, no llegaron a tiempo. En realidad, creemos que sería más acertado decir que los

72. No deja de ser ingeniosa y aguda la razón que da el cronista del por qué le mataron en aquel lugar. "El haberle dado muerte allí fue para que desde la torre pudiesen ver los guardias y la señora del teniente de la Guardia Civil (ya muerto en la refriega), fortificados en aquel lugar, lo que se hacia en la persona del cura párroco, y tuviesen entendido que a ellos también había de caber la misma suerte si persistian, como había persistido el padre, en no reconocer el nuevo gobierno, o más bien, aquella anarquía que acababa de proclamarse en la provincia". (Libro de Difuntos, fol. 61.- Sinopsis, II., 360).

73. El Libro de Defunciones las detalla rigurosamente con las fechas y años de estancia en las mismas. 
mandos cometieron errores de bulto y no estuvieron a la altura de las circunstancias. El P. Andrés Ferrero se lamenta de que no llegaran los auxilios a su debido tiempo; pero se lamenta mucho más de que cuando llegaron, no remataron la acción militar, tomando por asalto la citada hacienda de Imus, ya en poder de los rebeldes, alegando que las tropas españolas de Manila solamente habían salido para "reconocer los puntos en que aquellos se encontraban", sin darse cuenta de que ya estaban cometiendo verdaderas atrocidades.

Mucho debieron hablar y cavilar el P. Learte y el P. Juan sobre lo que debian hacer. Cuando llegó hasta ellos el teniente de la Guardia Civil, Sr. Chacón, destinado en Imus, el cual corroboró las noticias que ya se tenían de la revolución, lamentándose al mismo tiempo de la mal entendida prudencia del gobernador civil, Sr. Farge, que no le había autorizado para prender a los más significados separatistas, como era su deseo. Fue entonces cuando determinaron retirarse todos al interior de la hacienda de los recoletos ${ }^{74} \mathrm{y}$ en ella defenderse hasta morir contra los insurrectos que comandaba el propio Emilio Aguinaldo. El ataque no se hizo esperar y ocurrió en la noche del 31 de agosto. Resistieron valientemente por varias horas. Por la mañana, el Sr. Chacón aconsejó la retirada pues no había nada que hacer. Así lo hicieron, huyendo por aquellos caminos con el temor de ser vistos por los enemigos. No se equivocaron. El martirio a que fueron sometidos los religiosos y los ultrajes que recibieron los cuenta en detalle el historiador de la provincia de San Nicolás de Tolentino de Filipinas ${ }^{75}$.

h) Hnos. Román Caballero de la Virgen del Plú, Jorge Zueco del Rosario, Bernardo Angós del Corazón de María, Victoriano López de la Virgen del Plú, Dámaso Goñi de la Virgen del Plú, Luis Garbayo.del Carmen y Julián Umbón del Corazón de María. Todos ellos beneméritos de la Orden. Humildes y trabajadores. Entregados a los trabajos manuales en la citada hacienda de Imus. Ejemplo vivo de piedad y laboriosidad para los filipinos que trabajaban en la misma finca. Modelo de religiosos. Almas sencillas y buenas

74. En la finca se reunieron, además de los padres mencionados, Learte y Juan, el teniente Chacón, el Cabo Juan Pérez con cuatro números, el teniente de Cuadrilleros, Domingo Lacsón, Isabelo del Rosario, los dos filipinos, y la servidumbre de la Casa-Hacienda.

75. L. RUIz, o. c., II., 351 ss. 
de verdad. Todos ellos fueron testigos de excepción de la tragedia de Imus. Por ellos no se húbiera abandonado la defensa de la hacienda; pero obedecieron pensando que de este modo salvaban sus vidas. El Señor quiso que, cuando más esperanzados estaban de conseguirlo, los insurrectos se arrojaran sobre elios, en emboscada, siendo todos cruelmente asesinados.

Los dos últimamente citados residian en la hacienda de Salitrán, cercana a la de Imus.

V. Víctimas de la jrevolución en la provincia de Bataan.

Al llegar a este punto, el cronista se duele de que el número de víctimas que en los primeros días de Septiembre de 1896 tuvo la corporación en muchos de sus hijos, algunos de ellos miembros conspicuos, se vio aumentado con las désgracias ocurridas en la provincia de Bataan y en las venerables figuras de los párrocos de Bagac y Morong, los religiosos José Sanjuán y Domingo Cabrejas.

Con tiempo, el vicario de aquella provincia había avisado al provincial que los mencionados curas párrocos habían caído prisioneros de los insurrectos. Efectivamente, en los primeros días de noviembre las turbas revolucionarias asaltaron el convento dominicano de Hermosa, en la citada provincia de Bataan, asesinando al P. David Varas, de la misma Orden. Este hecho que, en un principio, pudo parecer insignificante, fue suficiente para que el superior mayor de los recoletos enviara un pequeño vapor para recoger a los misioneros que ejercian la cura de almas en varios pueblos de aquella provincia.

Embarcado el P. Alejandro Echazarra y recogido poco después el $P$. José Sanjuán, párroco de Bagac, el vaporcito se dirigió a Morong con el fin de recoger asimismo al P. Domingo Cabrejas. Al acercarse a este último pueblo, notaron con sorpresa cómo se habían concentrado pequeños núcleos de gente en la playa en los que advertían aviesas intenciones. Eran voluntarios encargados de proteger el orden y velar por la vida del párroco; pero su acción, en la mayor parte de los casos, fue hasta contraproducente. Embarcaron nuevamente todos déspués de comer tranquilamente en la casa del citado P. Domingo y en poco tiempo estuvieron en Manila. Pero aquellos celosos misioneros no podian estar inactivos y sí 
preocupados por la suerte de sus feligreses. Por lo que, con permiso del superior mayor, y a sabiendas del peligro que corrían, decidieron volver a sus respectivas parroquias. Aunque no la temían, es casi seguro que no esperaban su muerte tan temprana a manos de los rebeldes que cometieron atroces y verdaderos atropellos con sus cuerpos a juzgar por lo que leemos en las crónicas y en los testigos que presenciaron su martirio ${ }^{76}$.

La venganza, por parte de los españoles, no se haría esperar. Una vez que los soldados tomaron el pueblo de Morong, donde se cometieron los dos terribles asesinatos, el capitán Estévez cogió prisionero al responsable mayor de aquellos atropellos, el sanguinario y famoso Narciso Bugay, reunió a todo el pueblo, le exigió vestirse como de fiesta $y$, encaminados al mismo sitio donde habían cometido tan execrables sucesos, delante de todos lo mandó fusilar.

Entretanto, los dos religiosos, horriblemente mutilados, fueron sepultados dentro de los muros de la antigua iglesia del citado pueblo de Morong.

a) Baldomero Abadía de la Virgen de la Piedad. Para el autor del Libro de Difuntos es la décima séptima, para nosotros es una víctima más de la revolución filipina. Aragonés, del pueblo de Jarque, en la provincia de Zaragoza, ingresó en la Orden de agustinos recoletos en el colegio de Monteagudo el año 1886. Embarcó para el archipiélago en la barcada de 1892 a bordo' del correo "Santo Domingo", saliendo del puerto de Barcelona exactamente el día 19 de agosto. Ordenado de sacerdote el año siguiente, se le destinó a la provincia de Zambales, donde en compañía del párroco, P. Andrés Romero, se dedicó al estudio del idioma de aquella región ${ }^{77}$.

$Y$ fue en el pueblo de Alaminos donde permaneció por una temporada; hasta que se le designó él pueblo de O,Donnell como campo de labor apostólica en calidad de ayudante del P. Patricio

76. El P. Licinio Ruiz se detiene en la narración de los hechos y emplea, creemos que un tanto exageradamente, términos tan duros, que nosotros no nos atrevemos a reproducir por el decoro y respeto que merece siempre una persona por vil y criminal que ésta sea.

77. El autor del Necrologio dice que la primera misa del $\mathbf{P}$. Abadía dejó recuerdo imperecedero en el pueblo de Alaminos, donde la celebró con gran acompañamiento de agustinos recoletos y dominicos de la provincia de Pangasinán, y en un acto que revistió todos los caracteres de un acontecimiento. 
Ruiz. Prometía ser todo un misionero. En el ministerio parroquial dio pruebas inequívocas de un celo nada común por la salvación de las almas. En seguida se dedicó a la reparación de la iglesia y del convento y a mejorar en lo posible todo lo perteneciente al culto.

La revolución le sorprendió justamente en O,Donnell. El 30 de octubre de aquel aciago 1896 tuvo noticia el $P$. Baldomero de que en las inmediaciones del pueblo habia varias partidas de paisanos en actitud muy sospechosa, ya que todos los indicios eran de que intentaban dar un asalto por distintos puntos y a la misma hora. Nuestro misionero avisó rápidamente al que llamaban capitán municipal encargado del orden y de la defensa del poblado, el cual se presentó inmediatamente en el convento y le encargó que enviara vigilantes a las afueras del pueblo para, de este modo, averiguar si eran ciertos aquellos rumores.

Al día siguiente, domingo y 31 de octubre, después de la misa mayor, entraron a saludar al misionero, según costumbre, el citado capitán municipal y los demás "principales" de O,Donnell. EI $P$. Baldomero aprovechó aquella ocasión para increpar duramente al jefe por no haber cumplido el encargo que le diera de vigilan$\mathrm{cia}^{78}$. Esperó luego a que trajeran los niños a bautizar según estaban avisadas las familias, y como no viniese nadie, se acercó dando un paseo hasta cerca de una casa, propiedad de un feligrés por nombre Catalino. Se quedó hablando con los que estaban asomados a una de las ventanas, cuando de improviso salieron cinco individuos de detrás de la casa, machete en mano, y se arrojaron sobre el religioso, sin que le dieran tiempo a sacar el revólver que lievaba en el bolsillo para su defensa.

Era la hora señalada por los insurrectos, puestos en inteligencia con la gente del pueblo, para dar el asalto definitivo. Por distintos puntos aparecieron las partidas y una de èllas se acercó hacia donde estaba amarrado el P. Baldomero. Entonces -icosa extraña!- el que parecía câbecilla increpó a los bandidos que lo habían apresado diciéndoles:

— ¿Por qué amarráis así al padre? ¿Qué mal os ha hecho? ¿No

78. El cronista afirma que el oficial agachó la cabeza sin decir palabra alguna y salió en seguida del convento con toda la principalía. 
os daba cuanto tenía y se sacrificaba por vosotros? Soltadlo ahora mismo, o de otro modo seréis juzgados y pasados por las armas".

Obedecieron al instante; y dirigiéndose entonces al misionero, le dijo: "Ya estás libre. No tienes que preguntar a quién se lo debes: ya lo has visto. Ahora puedes marchar; pero en dirección opuesta al lugar en que están destacados los "castilas", porque si vas allá, morirás con ellos. Así, pues, vete al monte próximo donde estarás seguro".

Mas tan pronto como el P. Baldomero se vio libre, echó a correr, no precisamente en dirección al monte, sino hacia el destacamento de los españoles, compuesto de 25 hombres al mando de un teniente. Corría el agustino, y corrían detrás de él los nativos. Cerca del destacamento le dieron alcance y allí mismo le asesinaron. Entretanto, el pueblo de O,Donnell estaba siendo pasto de las llamas y arrasado ${ }^{79}$.

El autor del Catálogo es sumanente parco con este religioso. Después de decirnos que fue destinado al ciłado pueblo de O,Donnell, escribe textual: "Allí estuvo Ilenando cumplidamente las funciones de su sagrado ministerio, pues era un joven de angelicales costumbres y de espíritu verdaderamente apostólico, hasta el 31 de octubre de 1897, en que, habiendo entrado en dicho pueblo una partida de insurrectos, lo sacrificaron inhumanamente en odio a la Religión y a España" ${ }^{80}$.

b) José Sanjuán del Niño Perdido. Había nacido en Tabuenca ${ }^{81}$, provincia de Zaragoza, el 9 de diciembre de 1853. Tomó el hábito agustiniano en el colegio de Monteagudo el 25 de octubre de 1871. Arribó a las playas filipinas a bordo del navío "León" ${ }^{82}$ en enero de 1878. Casi podemos decir que no conoció otro puesto de misión que el de Bagac, en la provincia de Bataan, y alli estaba cuando comenzó la insurrección filibustera.

79. En el manuscrito que tenemos a la vista y que seguimos de cerca leemos que, habiéndose salvado el teniente de la Guardia Civil que en la mañana del domingo había estado con el padre "echando una copa" -escribe literal-, malherido llegó a Manila y allí preguntó a los recoletos por el paradero del P. Abadía, pues lo ignoraba; lo cual indica que los del fuerte ni se dieron cuenta de lo que habia ocurrido tan cerca de ellos. Cosa harto extraña; pero asi lo vemos escrito y así lo consignamos.

80. F. SADABA, o. c., 692.

81. El autor del Catálogo lo hace natural de Tarazona. (Ibid., 604).

82. Es curioso cómo el Necrologio nos da casi siempre el nombre del vapor en que fueron embarcados los misioneros. 
Habiendo salido de su parroquia el 25 de diciembre de 1896, terminados los oficios de Navidad - nos dice ahora el P. Sádabapara visitar a su colateral, P. Domingo Cabrejas y estando preparándose para celebrar la misa en la parroquia de éste, Morong, el 26 por la mañana, una turba de foragidos y desalmados penetró en la iglesia y convento, asesinando sacrílegamente a los dos indefensos religiosos, siendo de notar que el $P$. Cabrejas hallábase ya revestido de los sagrados ornamentos y hasta, según alguna relación, celebrando el incruento Sacrificio cuando se perpetró tan horrendo y execrable crimen ${ }^{83}$.

c) Domingo Cabrejas del Santísimo Cristo de la Columna. Natural de Mallón, Zaragoza. A los 17 años ingresó en el convento de recoletos de Monteagudo, prófesando de votos simples el 6 de septiembre de 1879. Embarcó para Filipinas en el vapor "Isla de Cebú", que salió de Barcelona el primero de junio de 1884. Administró varias parroquias tagalas; hasta los días tristes de la revolución, arriba reseñados, siendo párroco de Morong, donde fue asesinado junto con su compañero y amigo, el citado P. José Sanjuán ${ }^{84}$.

VI. Víctimas de la revolución en Zambales.

Zambales nos recuerda una de las páginas más gloriosas de la Recolección, regada con los sudores y las fatigas de los agustinos que sembraron incansables en su suelo y cultivaron con entusiasmo la semilla del amor y fe cristianas.

Esto escribe, más o menos, el historiador de la Orden ${ }^{85}$. Efectivamente, la provincia recoleta de San Nicolás de Tolentino regentaba hermosas parroquias en el norte de aquella zona. La revolución hizo aquí también sus víctimas que pertenecen ya a los últimos momentos de la misma, es decir, al año 1898, y, como diría el continuador del Necrologio - P. Francisco Ayarre de la Madre de Dios-, aunque no todos murieron en la demanda, ni fueron por el momento sacrificados por los sectarios del Katipunan, a todos, no

83. Sadaba, 1. c., 604.

84. Necrologio, fol. $70 \mathrm{v}$.

85. L. RUIZ, O. c., II., 403. 
obstante, cabe la gloria de haber defendido con varonil esfuerzo y con tesón inquebrantable los intereses que se les había encomendado. De tal modo, que los nombres de los religiosos Zacarías Biurrum, Juan Vicente, Marcelo Calvo, Silverio León y Vicente Beaumont únicos que sobrevivieron a la catástrofe, pueden figurar dignamente al lado de los que sucumbieron gloriosamente en ella.

El documento tiene un valor ahora excepcional. "Hallábase el que suscribe - dice el P. Francisco Ayarre- girando la visita a nuestros ministerios de Visayas, cuando a mediados de marzo de este año de 1898 recibí un telegrama de N.P. Fr. Santos Paredes, que había quedado en Manila de Vicario Provincial, comunicándome que en Zambales había ocurrido una gravísima novedad y que a todo trance urgía mi regreso a Manila, sin pérdida de tiempo, como así lo hice, habiéndome podido enterar a mi llegada a esta capital de la gran catástrofe ocurrida en la parte norte de la expresada provincia de Zambales ${ }^{86}$.

Con este testimonio por delante, nos adentramos por las páginas del Necrologio y proseguimos nuestra narración. Nadie nos suministra el dato aclaratorio sobre quién fuera el autor de la insurrección en Zambales. Solamente nos han dado a conocer los nombres de sus víctimas que en seguida hemos de reseñar.

a) Andrés Romero de la Concepción. Natural de Logroño, donde vio la luz primera el 14 de noviembre de 1850. Religioso agustino desde el 1868, arribó a las Islas Filipinas en la misión de 1872. Sacerdote desde el 73 , fue destinado a Zambales. La insurrección de esta provincia le sorprendió en el pueblo de Alaminos.

Siempre que llegamos a este punto, asistimos a la desagradable experiencia de la escasa guarnición de soldados españoles y más escasos miembros de la Guardia Civil con que contaban los destacamentos. En este lugar se encontraban solamente 22 cazadores y ocho números al mando del teniente Joaquín Palazón y del sargento Pales. Muy pocos para aquella multitud de nativos enfurecidos y hambrientos de matanzas españolas. Por lo que, bien pronto, todos ellos fueron pasados a cuchillo, no sin defender y pagar a un precio subido sus vidas.

El P. Andrés Romero fue hecho prisionero por los rebeldes, los

86. Necrologio, fol. 87 v. 
cuales le internaron en el bosque. Antes de que asistamos a su glorioso martirio, no queremos que pase desapercibida una fina observación que se hace el cronista y que trae precisamente en la reseña del $P$. Romero. Resulta que era a la sazón este religioso Vicario Provincial para Zambales y presentía días muy tristes para los españoles todos de Filipinas, de modo especial, para los religiosos. ¿Cómo, entonces, siendo superior mayor, no tomó a tiempo las medidas oportunas para salvar al personal que estaba bajo su jurisdicción? He aquí la peregrina respuesta que aporta el cronista y que extractamos al máximo: No se le ocultaba al $P$. Romero que, dada la tendencia que hay a tergiversar los actos de los religiosos a consecuencia de la guerra declarada por la masonería a las corporaciones religiosas, si tomaba la determinación de trasladar el personal de su vicaría a Manila, este acto se interpretaría torcidamente por las autoridades, sobre todo, por el Capitán General, don Fernando Primo de Rivera, que tenía verdadero interés en hacer creer al gobierno de Madrid que el país había quedado con el pastel (sic) de Biac-na-bató completamente pacificado. Prueba de este interés, desmedido en extremo, son los telegramas cruzados entre dicho Capitán General y el Ministro de la Guerra. Bien informado éste de lo que estaba ocurriendo en Zambales por los partes que le envió en repetidas ocašiones el cabo de Bolinao, preguntó al primer responsable militar del Archipiélago qué novedad había, y éste respondió que ninguna.

Este incidente llegó a hacerse público, con gran escándalo del mundo entero, por haberse ocupado del mismo toda la prensa, sin que hasta hoy -escribe el cronista- haya sido desmentido. No es, pues, de extrañar que el $P$. Romero, a pesar de abrigar serios temores de lo que iba a ocurrir en Zambales, no tomara medida alguna en lo tocante al traslado de sus religiosos a la capital de Manila, como sitio más seguro, por estar en ella la mayor y mejor fuerza de defensa en caso de producirse una nueva rebelión ${ }^{87}$.

El P. Vicario Provincial hubo de pagar caro este descuido, pues, cuando quiso darse cuenta del incremento que tomaba la insurrección de marzo en el norte de Zambales, fue hecho prisionero y, como otros de sus súbditos y hermanos, sacrificado en aquellas mismas fechas, en servicio de la Religión y de la Patria ${ }^{88}$.

87. Ibid., fol. $93 \mathrm{v}$.

88. El P. Sádaba nos dice de este religioso que poseyó con gran per- 
b) Manuel Azagra del Carmen. Nacido en Cintruénigo, provincia de Navarra, el 17 de julio de 1837, ingresó en los agustinos recoletos en marzo del año 1854, profesando al siguiente, y arribando a Filipinas en la misión que presidía el P. Pedro Polo en i858. El año de 1860 sería ordenado de sacerdote y destinado a Marinloc, en la provincia de Zambales. Administró la parroquia de Botolan hasta el 1867 en que fue trasladado al pueblo de Cabangaan. Más tarde pasó a la parroquia de Bolinao, donde le sorprendió la revolución del 98.

La "Memoria" manuscrita nos cuenta el suceso de la llegada de los insurrectos a aquel importante pueblo y coincide con otros relatos impresos. En la noche del 6 al 7 de marzo del citado 1898 Vicente Domenech recibió el aviso de que numerosas turbas insurrectas se dirigían sobre la población. Avisado el P. Azagra, éste le aconsejó que se viniera con su familia, compuesta por esposa y dos hijas, al convento como lugar más seguro. Pasada la noche en vela, de madrugada huyeron a la playa donde tenían preparada una pequeña embarcación ${ }^{89}$. Pero la mala suerte quiso que, como hubiere vuelto el $\mathrm{Sr}$. Domenech al convento a recoger el rifle que había dejado olvidado, llegaron a tiempo los insurrectos y tomaron prisioneros a nuestros fugitivos.

Pasemos por alto el calvario que sufrió nuestro paciente recoleto; lo mismo que las burlas y cuanto se puede suponer de que fueron objeto la esposa e hija del citado Domenech ${ }^{90}$. Lo que resulta indignante es que el principal cabecilla fuera uno que sólo había recibido favores del misionero y cuyo padre se decía amigo suyo. Se llamaba Pascual de Perio. Pudo salvar al religioso llevándole en la barca, propiedad suya, y en la que tenía depositados objetos y muchos fondos robados en distintas iglesias; pero no lo hizo; antes, le anunció que se preparase a bien morir, pues íba a encontrar a sus propias manos el remedio de sus desgracias. Su glo-

fección el dialecto de Zambales, habiendo escrito un diccionario, una gramática y una buena colección de sermones en dicho dialecto, originales unos y traducidos otros; mas todos estos trabajos fueron robados, si no destruidos, por las turbas lanzadas al campo en la época de la revolución. (F. SAdABA., o. c., 565).

89. A ellos se había unido don Eugenio Salcedo, español y ayudante de montes, y también el coadjutor de la parroquia, don Eugenio villanueva, sacerdote nativo.

90. Al final, esta familia pudo ser rescatada por las tropas españolas según nos asegura el Necrologio. 
rioso martirio acaeció a principios de marzo de 1898, según leemos en el Catálogo ${ }^{91}$.

c) Mariano Torrente de San Nicolás. Era natural de Barbastro y había visto la luz primera el 2 de agosto de 1832. El 24 de septiembre de 1850 profesó en la Orden de San Agustín, emitiendo sus votos en el tantas veces mencionado colegio de Monteagudo. Para entonces tenía terminada la carrera eclesiástica, por lo que emprendió pronto viaje a Filipinas. Destinado a la cura de almas, estuvo mucho tiempo en el pueblo de Balincaguin, pueblo muy castigado por las tormentas a consecuencia de hallarse sobre unas minas de hierro. Una de estas tormentas destruyó la iglesia que había restaurado y que en la noche del 17 de junio de 1865 fue presa de las llamas. El fuego se extendió también al convenio. Tra. tando el $P$. Mariano de salvar los objetos de más valor, sobre todo, los destinados al culto sagrado, le salió de improviso un individuo, lanza en ristre, impidiéndole salir afuera. Gracias a que el gobernadorcillo del lugar ${ }^{92}$ llegó a tiempo y pudo desarmarlo ${ }^{93}$, salvando la vida del religioso.

Repuesto del susto nuestro misionero ${ }^{94}$, se entregó de nuevo a la restauración de la iglesia y del convento que habían quedado reducidos casi a cenizas. El cronista se extiende en los detalles de la obra que llevó a cabo este excelente religioso en el mencionado pueblo de Balincaguin.

$Y$ este hombre bueno, benemérito bajo todos los aspectos, que sólo supo dar, recibió el premio de tantos sudores y trabajos siendo asesinado en la revolución que ya tenemos reseñada ${ }^{95}$.

d) Juan Navas del Carmen. Había nacido en el pueblo de

91. F. SADABA, o. c., 497.

92. Canuto Ferrero se llamaba este oportuno salvador del religioso.

93. En la declaración tomada al P. Mariano por el Sr. Alcalde Mayor de la provincia no se consigna la referida circunstancia del atropello. Por confidencias posteriores el propio $P$. Mariano supo que aquel individuo se llamaba Félix Freyre de Neyra, y que fue expulsado de la provincia como sujeto peligroso.

94. Sufrió varias quemaduras en la piel y quedó muy afectado del sistema nervioso.

95. El P. Francisco Ayarre, al tiempo de escribir la necrología de este religioso, ignoraba la suerte del P. Mariano, si bien suponía, y no se equivocaba, que seguramente había sido víctima de la insurrección junto con los 16 soldados y un cabo que defendían aquel destacamento. (Libro de Difuntos, fol., 90). 
Igea de Cornago, en la provincia de Logroño un 27 de enero de 1854, y profesado de agustino en 1872. Enviado a Filipinas en la misión que hacía el número setenta y dos y que salió de Barcelona en el mes de diciembre de 1877, llegó a Manila a principios del siguiente año.

Pronto le pusieron bajo la dirección del párroco de San Antonio, como era costumbre en estos misioneros. Recorrió luego diversos curatos de la provincia de Zambales. En 1889 le vemos ya de párroco del pueblo de Dasol. Y aquí estaba al tiempo de estallar la revolución de 1898. Fue muerto por los insurrectos de Zambales ${ }^{96}$.

VII. La persecución en Mindoro y Romblón.

La revolución filipina de 1898 no se limitó a la isla de Luzón, sino que se extendió a todas, se puede decir, provincias e islas del Archipiélago. Por lo que a los agustinos recoletos se refiere, nos queda por reseñar, siquiera brevemente y en el último párrafo de nuestro trabajo, lo ocurrido en las provincias de Mindoro y Romblon.

En los últimos meses del año 1898, después de haber tomado los americanos la ciudad de Manila, muchos religiosos se iban enterando de las proporciones gigantescas que había tomado el levantamiento en Filipinas. $Y$ fue entonces precisamente cuando se dieron cuenta de la situación crítica en que se encontraban. Con todo, permanecieron en sus puestos de trabajo, a pesar de que a medida que iban pasando los días iban recibiendo también nuevas noticias de la revolución. Los recoletos de la isla de Mindoro próxima a Manila, se encontraban casi en las mismas circunstancias de aislamiento e incertidumbre que los demás.

En los últimos días de mayo unos dos mil insurrectos atacaron las costas de la isla. Pronto se apoderaron de sus objetivos. En el mes de junio se presentaron en la hacienda que tenían los recoletos en Magarán. Los ocho religiosos que en ella se habían refugia-

96. E1 Necrologio no dice nada más de este misionero; y esto mismo repite a la letra el citado P. Sádaba en su obra. (Necrologio, fol. 94 del libro 2. - F. SADABA, o. c., 604). 
do esperando nuevas, habían conseguido huir a tiempo al monte. A una invitación del jefe de los insurrectos y fiados de su palabra bajaron a la referida hacienda y al punto, faltando a la palabra dada, fueron hechos prisioneros, siendo trasladados al pueblo de Mamburao. Desde este mismo instante comenzó el calvario, las humillaciones y los sufrimientos de nuestros misioneros que duraron cinco meses. En el mes de noviembre fueron trasladados a Batangas. $Y$ desde aquí a Lipa en donde quedaron a las órdenes del general Malvar. En esta misma ciudad, capital de provincia, estaban también prisioneros 600 cazadores españoles que, después de resistir valientemente el sitio, por espacio de doce dias, se vieron precisados a rendirse al enemigo.

Todavía tuvieron que recorrer varios destinos; hasta su último que fue el de Taisán, curato que había estado servido por religiosos recoletos. Recluídos aquí en una mísera casucha de nipa. no teniendo otro alimento que un poco de arroz mezclado con maíz, y sin otro consuelo que el de alguna persona caritativa que, de cuando en cuando, acudía a hacerles una visita, transcurrieron varios meses. Muchos de ellos cayeron enfermos de gravedad y alguno murió por efecto de aquel mal trato. Los que salvaron sus vidad a base de coraje y resistencia extrema recobraron la libertad el 19 de enero de 1899 en que entraron los americanos en el citado pueblo.

Parecida suerte corrieron los hërmanos de Romblón. Componían esta provincia varios pueblos diseminados en cuatro islas pequeñas, la más importanie la que llevaba el nombre de Romblón, cabecera de provincia y residencia del gobernador político-militar y demás autoridades judiciales y administrativas. El cronista nos dice que, aunque no muy distantes unas de otras, se hacía muy difícil su defensa en caso de alzamiento. Por lo que, llegado aquel triste momento, los religiosos, párrocos de los pueblos, se vieron completamente solos y a merced del enemigo.

Varios de los religiosos se ibán reuniendo en los conventos más seguros. Pero los acontecimientos se precipitaban; y por el mes de julio de 1898 llegó la noticia de que las tropas victoriosas de Aguinaldo se acercaban a Romblón. Eran bastantes los religiosos que allí se habian concentrado. Salieron del convento huyendo hacia el momento, y al día siguiente pudieron bajar a la playa y embarcar en una pequeña embarcación poniendo rumbo hacia el pueblo de Badajoz. 
Enterados los insurrectos de la marcha de los religiosos y demás españoles, salieron en su busca hasta que dieron con su paradero. De nuevo las amenazas y los malos tratos. De nuevo la marcha hacia distintos lugares; para volver a Romblón y quedar del todo incomunicados, si bien es verdad que en esta ocasión lo pasaron bas'ante mejor que la primera gracias a la caridad de los nativos que les proporcionaron de ropas y alimentos. En el pueblo de Mogpog estuvieron mejor atendidos y hasta bajo la vigilancia de unos buenos soldados de la insurrección. La libertad ansiada llegaría con la toma de la isla por los americanos, que fue ya por el mes de mayo de $190{ }^{97}$.

\section{EPILOGO}

Es posible que nuestro estudio haya quedado incompleto y que nos hayamos dejado en el olvido algunos sucesos dignos de aparecer en estas páginas. Tampoco hemos pretendido agotar el tema. Aparte de que hemos podido comprobar que los religiosos recoletos, misioneros en Cebú, o entre tagalos, siguieron la misma suerte que los hermanos calzados, cuya vida y hechos más importantes quedan estudiados en nuestra obra La persecución religiosa y la Orden de San Agustín en la Independencia de Filipinas ${ }^{98}$. El mismo cronista recoleto que tantos datos nos ha suministrado y cuyo orden cronológico y geográfico hemos seguido, reconoce que solamente ha intentado referir lo más saliente y principal, omitiendo detalles y circunstancias.

Quede aquí consignado igualmente cómo nuestro propósito se ha cumplido y el capítulo, glorioso e interesante, de los agustinos recoletos en la revolución filipina puede ya añadirse y formar parte de nuestro estudio principal.

Teófilo Aparicio

97. Para más detalles, conf. L. RuIz, Sinopsis..., II., 425 ss.

98. El P. Licinio trae, a modo de apílogo de la Revolución fillipina, algunos detalles que considera de interés y que le ha suministrado el $\mathbf{P}$. Bernabé Rena, testigo de los hechos, sobreviviente a los mismos y superior mayor en 1925. (Vid. Sinopsis histórica..., II., 460 ss.) 